\title{
ARCHEOMETRICKÉ STUDIUM RANĚ NOVOVĚKÉ KERAMIKY ZE SEVEROZÁPADNÍHO SLOVENSKA (ŽILINA, BUDATÍN A LIETAVA)
}

\author{
KAREL SLAVÍČEK - JAN PETŘÍK - SAMUEL ŠPANIHEL
}

\begin{abstract}
Abstrakt: Postmedieválni glazovaná keramika byla dosud ve střední Evropě zkoumána jen okrajově. Soubor hrnčiny ze Žiliny, Budatina a Lietavy umožňuje unikátni komparaci písemných pramenů a výsledků archeometrických analýz, které byly provedeny pomocí optické mikroskopie a energiově-disperzní rtg. fluorescenční spektrometrie (ED-XRF). S keramikou byly srovnány vzorky surovin - hlín - ze dvou historicky doložených hliniků (Bytčica, Trnové) a písčitého sedimentu z Váhu. U keramiky byl potvrzen lokální původ. Nádoby staršivrcholně středověké - tradice vykázaly větši regionální odlišnost. Mladší-novověká - keramika byla v regionu distribuována z dílen hrnčírského cechu v Žilině. Vzorek z Trnové - Hrnčiarsky vrch se chemickým složením bliži keramice dvou určených produkčnich skupin. Toto zjištěni koresponduje s obsahem artikul hrnčiřského cechu v Žilině, podle nichž měli hrnčíri jako surovinu využívat hlínu z Trnového a jako ostřivo písek z Váhu. Analyzované křemité glazury jsou vysoce olovnaté, většinou s př́davkem mědi nebo manganu jako pigmentu.
\end{abstract}

Klíčová slova: Žilina - raný novověk - keramika - glazury - přirodovědné analýzy.

Archaeometric study of early modern age pottery from north-western Slovakia (Žilina, Budatín and Lietava)

Abstract: Post-medieval glazed pottery has only been studied marginally in Central Europe. A pottery series from Žilina, Budatín and Lietava enables a unique comparison of written sources and the results of archaeometric analyses conducted by means of optical microscopy and energy-dispersive X-ray fluorescence spectrometry (ED-XRF). The pottery was compared with samples of clays from two historically confirmed clay deposits (Bytčica, Trnové) and sand sediments from the River Váh. The pottery proved to be of local origin. Older vessels from the high Middle Ages showed greater regional differences. Pottery from the modern age period was distributed in the region from the workshops of the potters' guild in Žilina. The chemical composition of a sample from Trnové - Hrnčiarsky vrch is close to the pottery of two determined production groups. This finding corresponds to the statutes of the potters' guild in Žilina, according to which potters were to use clay from Trnové as the raw material and sand from the Váh as temper. The analysed silica glazes have a high content of lead, and typically contain copper or manganese added as pigments.

Key words: Žilina - early modern age - pottery - glazes - archaeometry.

\section{1 Úvod}

Tato studie se věnuje problematice postmedievální glazované keramiky domácí produkce z počátku novověku. V rámci Slovenska jde o ojediněle zkoumanou problematiku, a v oblasti severozápadního Slovenska, respektive Horního Pováží a Kysuc, se jedná o pionýrskou práci. Zkoumaná keramika pochází z města Žilina a z hradů Budatín a Lietava. Výsledky získané pomocí odpovídajících archeometrických analýz jsou porovnávány s písemnými prameny, zejména s cechovými pravidly žilinského hrnčířského cechu.

Běžná novověká hrnčina byla dosud ve střední Evropě archeometricky studována jen velmi okrajově. K dispozici jsou výsledky starších analýz z Prahy a Berouna (Žegklitz-Zavřel 1990) a novější studie o novověké keramice z Turnova (Matějková 2011; Rzeznik-Stoksik 2011), kde se autorům podařilo odhadnout teploty výpalu a identifikovat pravděpodobně lokální a cizorodé produkční skupiny. Relevantní může být ještě srovnání s výsledky materiálových analýz glazovaných kachlů ze slovenských a mad'arských lokalit, které ovšem náleží 13.-15. století a byly publikovány jen předběžně a zatím bez údajů o složení glazur (Györkös et al. 2018).

Použití v současné době obvyklých metod archeometrického výzkumu keramiky (mikropetrografie kombinovaná s analýzou chemického složení) umožňuje detailnější pohled na běžnou raně novověkou hrnčinu ze šlechtických sídel a města ve studovaném regionu. Vybrané metody 
jsou vhodné pro validování makroskopicky definovaných keramických tříd či skupin (Čapek et al. 2018; Těsnohlídková et al. 2019), často je možné některé sporné třídy lépe popsat či rozdělit na tř́dy podle odlišného znaku odhaleného při mikropetrografické analýze. Srovnáním chemismu se zdroji jílovité suroviny je též možné identifikovat region původu keramické hlíny. Otázku provenience mohou zodpovědět úlomky hornin přítomné v keramické matrix, jejichž petrografie je závislá na složení podloží.

\section{Raně novověká keramika ze severozápadního Slovenska}

Nejstarší práce věnující se, alespoň okrajově, novověké keramice pochází z pera B. Polly (1962; 1986) a J. Hošša (1983; 1988). Tyto studie se sice primárně zaměřují na středověkou produkci, avšak je v nich nastíněna i tzv. přechodná etapa k novověké keramice. Novějším textem J. Hošša, který popisuje jednotlivé změny keramické produkce v přechodném období mezi středověkem a novověkem, je Hranica medzi stredovekom a novovekom vo svetle archeologických nálezov keramiky (2004, 569-580). V regionu severozápadního Slovenska na jeho práci navázal S. Španihel (2014; 2015; 2017), konkrétně zpracováním keramických souborů z hradu Lietava, z městského př́ikopu Žiliny a z barokní pevnůstky v lokalitě Čierná-Valy. Ani v jiných regionech Slovenska není novověká keramika úplně mimo oblast zájmu (Čurný 2004; Botoš 2012; Uličný 2004). Ve státech hraničících se severozápadním Slovenskem, tedy v České republice a Polsku, má výzkum postmedievální keramiky delší tradici. V Česku patří k nejvýznamnějším badatelům J. Pajer, který se kromě studia novokřtěnské fajánse věnoval i lokální hrnčině (1983). V tomto oboru jsou výrazně aktivní zejména pražští autoři (Blažková 2013; Blažková-Matějková 2016; Žegklitz 1990). V Polsku je novověká archeologie již etablovaným a poměrně rozšířeným oborem. Pro potřeby naší studie jmenujme jenom skupinu badatelů sdružující se kolem Vratislavské univerzity (Mackiewicz 2012; Szwed 2004; Zdaniewicz 2012).

Středověká keramická produkce na území dnešního Slovenska byla rozdělena do čtyř keramických okruhů. Území Karpatského oblouku, do kterého spadá i severozápadní Slovensko, představuje oblast s barevným střepem. Název je odvozený od načervenalého zbarvení oxidačně vypalované hrnčiny, která je pro tento region signifikantní. Jednotlivé výrobní okruhy překračují dnešní státní hranici a navazují na místní produkční oblasti. V případě severozápadního Slovenska jde o východní a severovýchodní Moravu, Slezsko a Malopolsko (Hoššo 1983, 220-224).

V raném novověku, př́ípadně již v tzv. přechodné fázi, se slovenské výrobní okruhy spojily a naprostou převahu získaly oxidačně pálené písčité keramické třídy načervenalé až okrové barvy, někdy s př́měsí muskovitu a aplastik prachovité či štěrkovité zrnitosti (Španihel 2014, 143; 2017, 301). Obecně lze říci, že raně novověká keramika v regionu severozápadního Slovenska kombinuje pozdně středověké prvky, které jsou pozorovatelné hlavně na keramice kuchyňské, konkrétně na hrncích, pokličkách a zadělávacích mísách, a nové novověké znaky, které převažují na keramice stolní, tedy na džbánech a mělkých mísách. Mezi základní vyšší hrncovité typy patří soudkovitý, později esovitý s jednoduchým vykloněným, často zesíleným, okrajem a jedním páskovým uchem. Džbány jsou obvykle vejcovité či lahvovité. Mezi stolní keramikou se často objevují válcovité hrnky, které podobně jako hrnce mohou nabývat soudkovitých či esovitých tvarů. Mezi mělkými mísovitými tvary převažuje jídelní mísa. Jde o mělkou nádobu s úzkým vykloněným okrajem různých forem, plynulým a proporčně tvarovaným profilem se širokým nástřepím a převážně konvexními stěnami (Španihel 2019, 257-259). Jídelní mísa byla určena ke společné konzumaci, např́íklad pro čeled', nebo sloužila k předkládání většího množství zejména tuhého jídla, jež bylo dále rozdělováno individuálním strávníkům, kteří mohli k dalšímu stolování používat (zvláště ve vyšší společnosti) keramický talír̆, nebo analogické, ale výrazně menší mísy (Plicková-Scheulfer 1966, 46). Zmíněný taliř patřil k méně zastoupeným nádobám a často napodobuje výrobky z jiných hmot, nejčastěji z tepaného plechu. Jde o plochou, mělkou nádobu na rubu vybavenou ovaleným nebo proloženým a prožlabeným okrajem. Mísovité nádoby doplňuje hluboká kónická mísa se zvratným okrajem, která sloužila také ke kolektivnímu stravování, ale pravděpodobně z ní byla konzumována zejména tekutá jídla. Pro tuto mísu (stejně jako pro džbán) je v 17. století typickým znakem celoplošné potírání 
černou olověnou glazurou (Španihel 2019, 272). Ve větším počtu se vyskytují ještě zadělávací mísy a trojnožky. Oba typy nádob vychází ze středověké hrnčířské tradice. Hrubá válcovitá, příležitostně mírně vypouklá zadělávací mísa (tzv. pernice) je nádoba specifická svou keramickou hmotou, jejímž výběrem bylo pravděpodobně substituováno umělé zdrsnění vnitřku nádoby. Trojnožka se přechodem do novověku výrazně nemění. Nejobvyklejšími novověkými znaky jsou jednoduché ploché dno a rukojet' ukončená knoflíkovým uzávěrem. $Z$ dalších nádob je možné zmínit zvoncovité pokličky, které v novověku ztrácejí typickou esovitou profilaci a stávají se mělčími. Ojediněle se vyskytnou i poklice o průměru $30 \mathrm{~cm}$ s páskovým uchem, které pravděpodobně sloužily k překrývání mís (Španihel 2019, 263). Z málo se vyskytujících nádob je třeba zmínit cedníky, poháry či kahany.

Materiálová a morfologická unifikace stolní a kuchyňské keramiky snížila oproti stř̌edověku variabilitu keramických tříd. Primárním chronologickým, ale i sociálním determinantem se stává výzdoba, u které došlo na počátku novověku k typovému rozšiření. Mechanická výzdoba zůstává dominantní (rytá, kolkovaná či radélkovaná), ale připojuje se k ní výrazná malovaná dekorace založená na barevném kontrastu glazur a hlinek. Umělecké provedení přechází od jednoduchých amorfních fleků až po složité malované geometrické a figurální motivy. Na území Slovenska se jedná zejména o motivy vegetativní a zoomorfní (Hoššo 2004, 571; Pajer 1983, 5). Glazované zboží se začalo v regionu objevovat na přelomu 15. a 16. století. Jedná se o olověnou transparentní glazuru, která má nejčastěji zelený odstín. Poměrně hojně se objevuje i glazura bezbarvá (Španihel 2014, 147; 2019). Začátkem 17. století se začala používat glazura černá, která byla aplikována zejména na povrch džbánů, hrníčků a ojediněle hrnců. Největší rozmach tohoto typu glazury spadá až do století následujícího (Májsky 2003, 66; Španihel 2014, 155).

\section{Hrnčířský cech v Žilině}

Obchodním a výrobním centrem západní poloviny oblasti, kde byl rozšířen barevný střep, byla Žilina. Město, které leželo na křižovatce cest spojujících Severní Uhersko s Polskem a zejména Slezskem (Španihel 2015, 857-859). Městský hrnčířský cech vznikl pravděpodobně kolem poloviny 16. století, protože k roku 1559 se připomíná cech hrnčiřro̊ a kovářů, který se řídí společnými artikuly. Tato zmínka pochází z Articuli honestae cehae figulorum Solnensium, tedy Artikulů počestného cechu hrnčířu žilinských, jejichž úvodní části byly sepsány pravděpodobně v roce 1582 . Zdejší cech plnil funkci oblastní organizace, protože někteří členové nejenže nebydleli přímo ve městě, ale pocházeli dokonce i z jiných panství. Vhodným př́ikladem je Štefan Suchánek z Košece, která je od Žiliny vzdálená přibližně 55 km (Jeršová 1960, 313). Samotné administrativní zařazení Žiliny v průběhu sledovaného období je poměrně složité. Původně sice byla součástí lietavského panství, avšak jako největší město regionu pravidelně využívala př́iležitostné oslabení majitele Lietavy a pomocí královské podpory se snažila z lietavského poddanství vyvázat či se případně přidat do některého ze sousedních panství, kde jí byly slibovány lepší podmínky. Definitivně se Žilina oddělila od lietavského panství svatbou Anny Kostkové se Štefanem Deršfim v roce 1540, kdy přešla pod panství Strečno (Kavuliak 1941, 56-57). Lietavské dominium si i navzdory této významné ztrátě zachovalo v rámci Uherska vcelku silné postavení, a to díky faktu, že v průběhu předcházejícího století zabralo celé sousední panství, původně patřící již zaniklému hradu Rajec. Ziskem rajeckého panství se lietavské dominium rozrostlo o osm vesnic a trhové, později zeměpanské městečko Rajec, které je z pohledu této práce zajímavé tím, že v jsou v něm v průběhu 17. století zmiňovány hrnčířské dílny. Město samo však cech nemělo (Fekete-Nagy 1941, 71; Lengyelová 2012, 132-133).

Ze soupisu cechovních předpisů jsou pro cíle této studie důležité zejména dva artikuly. Z původní verze pochází artikul č. 23 , který se věnuje podmínkám pro splnění tovaryšské zkoušky neboli majsterštuku. Citovaný úryvek vhodně ilustruje nejen dobovou produkci, ale také část výrobních postupů: „Hrnec veliký, co by byl na tri piadi a na tri prsty zvyše udielaný z jedného kusu hliny. Džbán také na tri piadi a na tri prsty zvyše udielaný z jedného kusu hliny. Dujnica, jako jest kruh na širky také z jedného kusu hliny udielaná. Misa veliká, jak muže nejvetši býti udielaná, vrch na loket z širky také z jedného kusa hliny.“ 
Druhý významný artikul je označen číslem 27 a byl připojen v roce 1609 . Z jeho obsahu se dá vyčíst důležitá informace o historickém a technologickém rozvoji hrnčířství v Žilině. Artikul totiž upravuje nákup glejdy (glazury) cechovými mistry. Glazura byla potřebná pro výrobu tzv. panských věcí - pravděpodobně šlo o materiální dávku odváděnou vrchnosti nebo nádobí určené pro vyšší společenskou vrstvu, jež nebylo v té době ještě všeobecně rozšířené (Jeršová 1970, 69). Jedná se o první zmínku o glazování keramiky v regionu, která zároveň dokládá, že glazování již bylo mezi žilinskými hrnčíři všeobecně rozšířeno. Druhá část tohoto artikulu se zmiňuje o zdrojích jednotlivých surovin - hlínu nakupoval cech ve dvou obcích - Bytčici a zejména v Trnovém (,... též $i$ od chotára do Trnoweho každoročne platiti se musí, s kterého hlinu k našemu remeslu bereme..."), červené hlinky se těžily na úpatí vrchu Minčol v Malé Fatře a kameny do glazury a ostřiva pocházely z řeky Váh, níže pod městem.

Žilinský cech byl hlavním producentem keramiky v oblasti až do druhé čtvrtiny 18. století, kdy se začaly objevovat první negativní zprávy komentující převážně špatný ekonomický stav organizace. Nakonec byl roku 1872 cech zrušen zákonem (Celoštátny priemyselný zákon; Jeršová 1970, 68; Vitkóová 2015, 82).

\section{Geologické poměry}

Důležitým činitelem ovlivňujícím složení potenciálních hrnčířských surovin v okolí Žiliny je řeka Váh, jejíž snosová oblast zahrnuje několik jaderných pohoří Západních Karpat. Fluviální sedimenty uložené v nivě Váhu tedy mohou obsahovat pestrou varietu hornin a minerálů zahrnující hlubinné vyvřelé horniny a horniny z metamorfovaného obalu i sedimentární horniny z jejich prríkrovů. Složení hrnčířských surovin může být také ovlivněno místní geologií, především v př́ípadě, že by jako zdroj suroviny byly použity místní koluvia nebo půdy. Geologická stavba okolí Žiliny je ilustrována přiloženou geologickou mapou (obr. 1). V okolí se vyskytují především sedimentární horniny, a to jak klastické (jílovce, slínovce, pískovce, slepence), tak karbonáty (vápence, dolomity). V rámci širšího okolí Žiliny byly ovzorkovány zdroje hrnčířských surovin známé z historických pramenů (viz kapitolu 3) a také sedimenty uložené v nivě Váhu. Lokalizace odebraných vzorků hlíny a sedimentů je zobrazena na mapě (obr. 1 a 2).

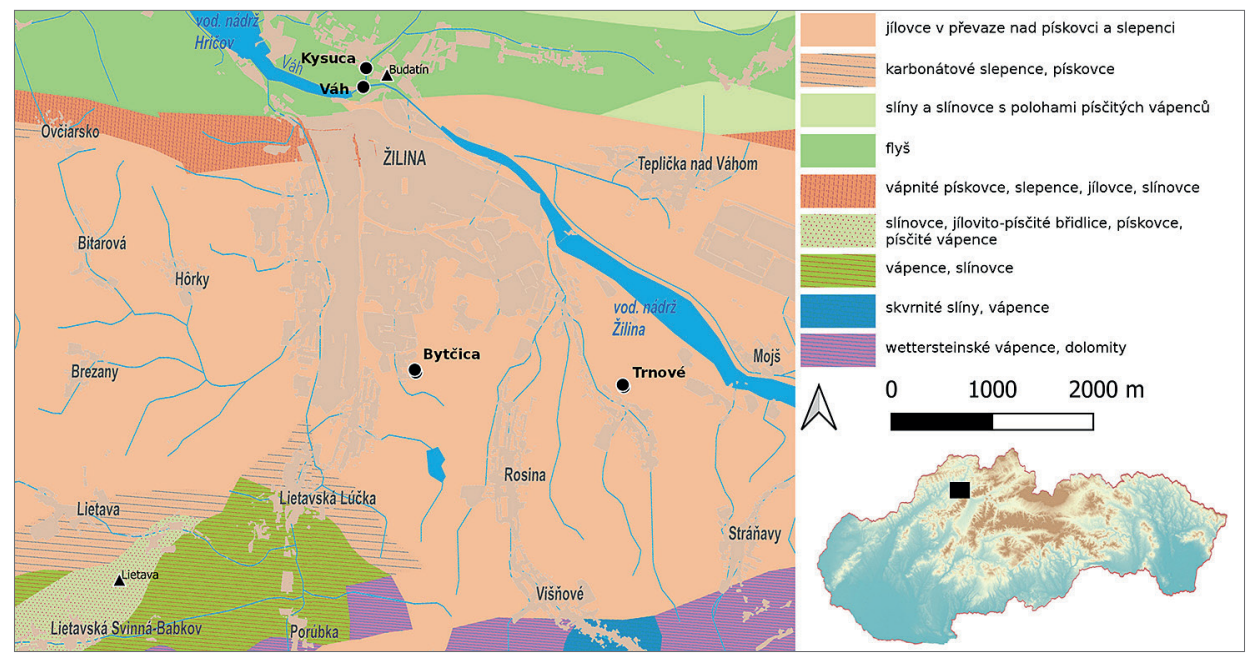

Obr. 1. Geologická mapa regionu, vyznačena místa původu keramiky a odběru vzorků hlín a ostřiva. Podle Vozár-Káčer 1998; upraveno.

Abb. 1. Geologische Karte der Region, mit Kennzeichnung der Stellen, von denen die Keramik und die Probenentnahmen von Lehm und Magerungsmittel stammen. Nach Vozár-Káčer 1998; bearbeitet. 


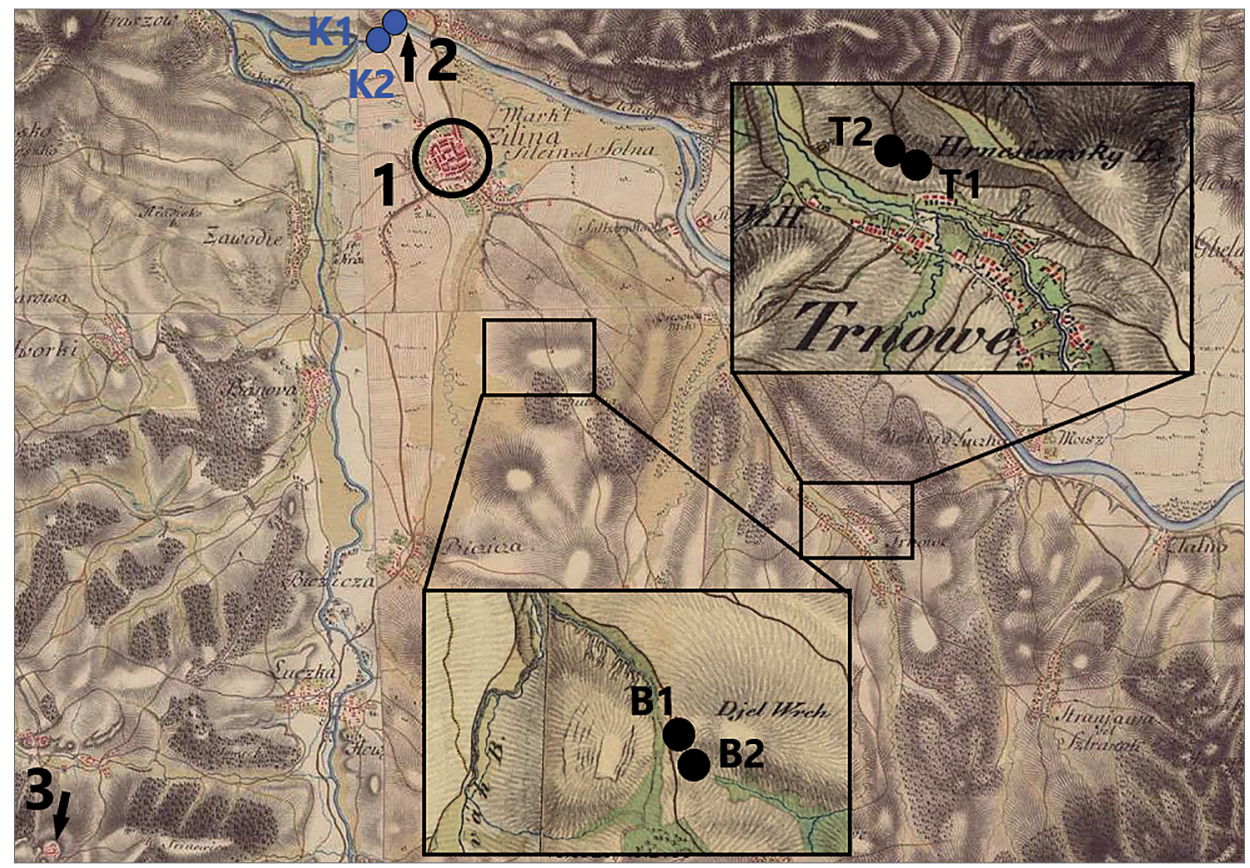

Obr. 2. První vojenské mapování (1782-1784), do kterého jsou vloženy výřezy z druhého vojenského mapování s doloženými názvy sledovaných těžebních lokalit (1819-1858). 1 - Žilina; 2 - Budatín; 3 - Lietava.

Abb. 2. Erste militärische Kartierung (1782-1784), mit Ausschnitten von der zweiten militärischen Kartierung mit belegten Namen der beobachteten Abbaustellen (1819-1858). 1 - Žilina; 2 - Budatín; 3 - Lietava.

\section{Vzorky a metodika}

Pro tuto studii bylo vybráno 27 fragmentů nádob, typického zboží raného novověku, reprezentujících čtyři nejpočetnější keramické třídy na daném území (tab. 1, obr. 3). Vzorky pochází z výzkumů hradů Budatína a Lietavy a města Žiliny. Z každé lokality byly vybrány vzorky se stejnými typy glazur: transparentní bezbarvá a zelená a také černá neprůhledná. Typologicky vzorky zastupují pět druhů nádob - hrnec, zadělávací mísa, džbán, jídelní mísa (či talíř) a zvoncovitá poklice. Ve zkoumaném souboru jsou tedy zastoupeny jak keramika kuchyňská, tak keramika stolní.

Sledované lokality jsou město Žilina, Budatínsky hrad a hrad Lietava. Keramika pochází vždy ze stratifikované situace. Lietavský soubor byl získán v roce 2011 (Bielich v tisku) při výzkumu Kynisiho paláce, který v novověku sloužil jako hospodářský objekt složený z centrální kuchyně hradu, pekárny a skladovacích prostor. Vzorky pochází ze sondy č. 10, která byla položena v hlavní místnosti paláce. Získaná keramika náleží kontextu č. 10, výjimku tvoří fragmenty č. 17 a 25, které byly exkavovány z kontextu č. 13 (Španihel 2019, 130-131). Budatínsky hrad byl zkoumán v letech 2006 a 2007 P. Bednárem a Z. Stanekovou (2009, 29-31, 208 obr. 8) a vzorky byly získány primárně při výzkumu centrální věže (vzorky č. 5, 6, 15, 18, 28 - zásyp přízemí). Další vzorky jsou ze sondy VI (č. 14 - kontext 6003), která byla umístěna na jižní terase, tedy v jádru dnešního hradu, a dále ze sond VIII (č. 8, 9 - kontext 8051, č. 16 - kontext 6017) a XIX (č. 13 - kontext 19 014), které byly situovány v interiéru východní části hradu. Všechny žilinské nálezy pocházejí z Mariánského náměstí, které bylo zkoumáno jednou, kontextuálně nerozlišenou, sondou v prostoru pod dnešní fontánou v letech 1966 a 1993 (Moravčík 1970, 20-22). 
Tab. 1. Seznam vzorků a druh analýzy, které byly podrobeny. OM - optická mikroskopie, ED-XRF - rtg. fluorescenční spektrometrie.

Tab. 1. Verzeichnis der Proben und Analysen, denen sie unterzogen wurden. OM - optische Mikroskopie, ED-XRF - Rtg. Fluoreszenzspektrometrie.

\begin{tabular}{|c|c|c|c|c|c|c|c|}
\hline ID & Inv. č. & Tvar nádoby & $\begin{array}{c}\text { Keramická } \\
\text { třída }\end{array}$ & Lokalita & $\mathrm{OM}$ & $\begin{array}{c}\text { ED-XRF } \\
\text { (keramika) }\end{array}$ & $\begin{array}{l}\text { ED-XRF } \\
\text { (glazura) }\end{array}$ \\
\hline 1 & $249 / 2014$ & zad. mísa & $\mathrm{T} 1$ & Lietava & $\mathrm{x}$ & $\mathrm{x}$ & - \\
\hline 2 & $\mathrm{x} 1$ & zad. mísa & $\mathrm{T} 1$ & Lietava & $\mathrm{x}$ & $\mathrm{x}$ & - \\
\hline 3 & $\mathrm{x} 2$ & zad. mísa & $\mathrm{T} 1$ & Lietava & $\mathrm{x}$ & $\mathrm{x}$ & - \\
\hline 4 & $\mathrm{x} 3$ & hrnec & $\mathrm{T} 2$ & Lietava & $\mathrm{x}$ & $\mathrm{x}$ & - \\
\hline 5 & ZA-BZ-41 & talířrjd. mísa & $\mathrm{T} 3$ & Budatín & $\mathrm{x}$ & $\mathrm{x}$ & $\mathrm{x}$ \\
\hline 6 & ZA-BZ-50 & hrnec & $\mathrm{T} 3$ & Budatín & $\mathrm{x}$ & $\mathrm{x}$ & $\mathrm{x}$ \\
\hline 7 & $286 / 2014$ & hrnec & $\mathrm{T} 3$ & Lietava & $\mathrm{x}$ & $\mathrm{x}$ & - \\
\hline 8 & ZA-BZ 243/07 & talířrjd. mísa & $\mathrm{T} 1$ & Budatín & $\mathrm{x}$ & $\mathrm{x}$ & - \\
\hline 9 & ZA-BZ 248/07 & hrnec & Т 2 & Budatín & $\mathrm{x}$ & $\mathrm{x}$ & - \\
\hline 10 & Ž7-1 & džbán & $\mathrm{T} 10$ & Žilina & $\mathrm{x}$ & $\mathrm{x}$ & - \\
\hline 11 & Ž7-2 & džbán & $\mathrm{T} 10$ & Žilina & $\mathrm{x}$ & $\mathrm{x}$ & - \\
\hline 12 & ZA-BZ442 & hrnec & $\mathrm{T} 2$ & Budatín & - & $\mathrm{x}$ & - \\
\hline 13 & ZA-BZ131 & hrnec & $\mathrm{T} 2$ & Budatín & - & $\mathrm{x}$ & - \\
\hline 14 & ZA-BZ39 & džbán & T3 & Budatín & - & $\mathrm{x}$ & - \\
\hline 15 & ZA-BZ182 & zad. mísa & $\mathrm{T} 1$ & Budatín & - & $\mathrm{x}$ & - \\
\hline 16 & 286/2014-b & hrnec & $\mathrm{T} 3$ & Lietava & - & $\mathrm{x}$ & - \\
\hline 17 & ZA-BZ41b & hrnec & $\mathrm{T} 3$ & Budatín & - & $\mathrm{x}$ & $\mathrm{x}$ \\
\hline 18 & Mn 18 & hrnec & $\mathrm{T} 3$ & Žilina & - & $\mathrm{x}$ & $\mathrm{x}$ \\
\hline 19 & $\mathrm{Mn} 7-1$ & zv. poklička & $\mathrm{T} 10$ & Žilina & - & $\mathrm{x}$ & - \\
\hline 20 & Mn7-2 & džbán & $\mathrm{T} 10$ & Žilina & - & $\mathrm{x}$ & - \\
\hline 21 & Lietava-trieda2-1 & hrnec & $\mathrm{T} 2$ & Lietava & - & $\mathrm{x}$ & - \\
\hline 22 & Lietava-trieda $2-2$ & hrnec & $\mathrm{T} 2$ & Lietava & - & $\mathrm{x}$ & - \\
\hline 23 & Lietava-trieda2-3 & hrnec & $\mathrm{T} 2$ & Lietava & - & $\mathrm{x}$ & - \\
\hline 24 & 338-2014 ZG & talíŕ/jd. mísa & $\mathrm{T} 3$ & Lietava & - & $\mathrm{x}$ & $\mathrm{x}$ \\
\hline 25 & 338-2014 ŽG & hrnec & $\mathrm{T} 3$ & Lietava & - & $\mathrm{x}$ & $\mathrm{x}$ \\
\hline 26 & 340-2014 ČG & hrnec & $\mathrm{T} 3$ & Lietava & - & $\mathrm{x}$ & $\mathrm{x}$ \\
\hline 27 & ZA-BZ-35-2 & hrnec & $\mathrm{T} 3$ & Lietava & - & $\mathrm{x}$ & $\mathrm{x}$ \\
\hline 28 & - & - & sediment & Trnové - Hrnčiarsky vrch & - & $\mathrm{x}$ & - \\
\hline 29 & - & - & sediment & Trnové - Hrnčiarsky vrch & - & $\mathrm{x}$ & - \\
\hline 30 & - & - & sediment & Bytčica - Hlinisko & - & $\mathrm{x}$ & - \\
\hline 31 & - & - & sediment & Bytčica - Hlinisko & - & $\mathrm{x}$ & - \\
\hline 32 & - & - & sediment & Váh & - & $\mathrm{x}$ & - \\
\hline
\end{tabular}

Žilina byla zvolena jako přirozené regionální obchodní a zejména řemeslné centrum, odkud jsou navíc dochovány výše zmíněné hrnčiřské artikuly. Budatínsky hrad díky své poloze v těsné blízkosti Žiliny představuje lokalitu v nejbližším zázemí produkčního centra. Hrad Lietava, vzdálený od Žiliny přibližně $12 \mathrm{~km}$, byl ve sledovaném období majetkem rodu Turzo, jehož čelní představitelé se pohybovali ve vrcholné uherské politice a Juraj VIII. dokonce dosáhl na post 


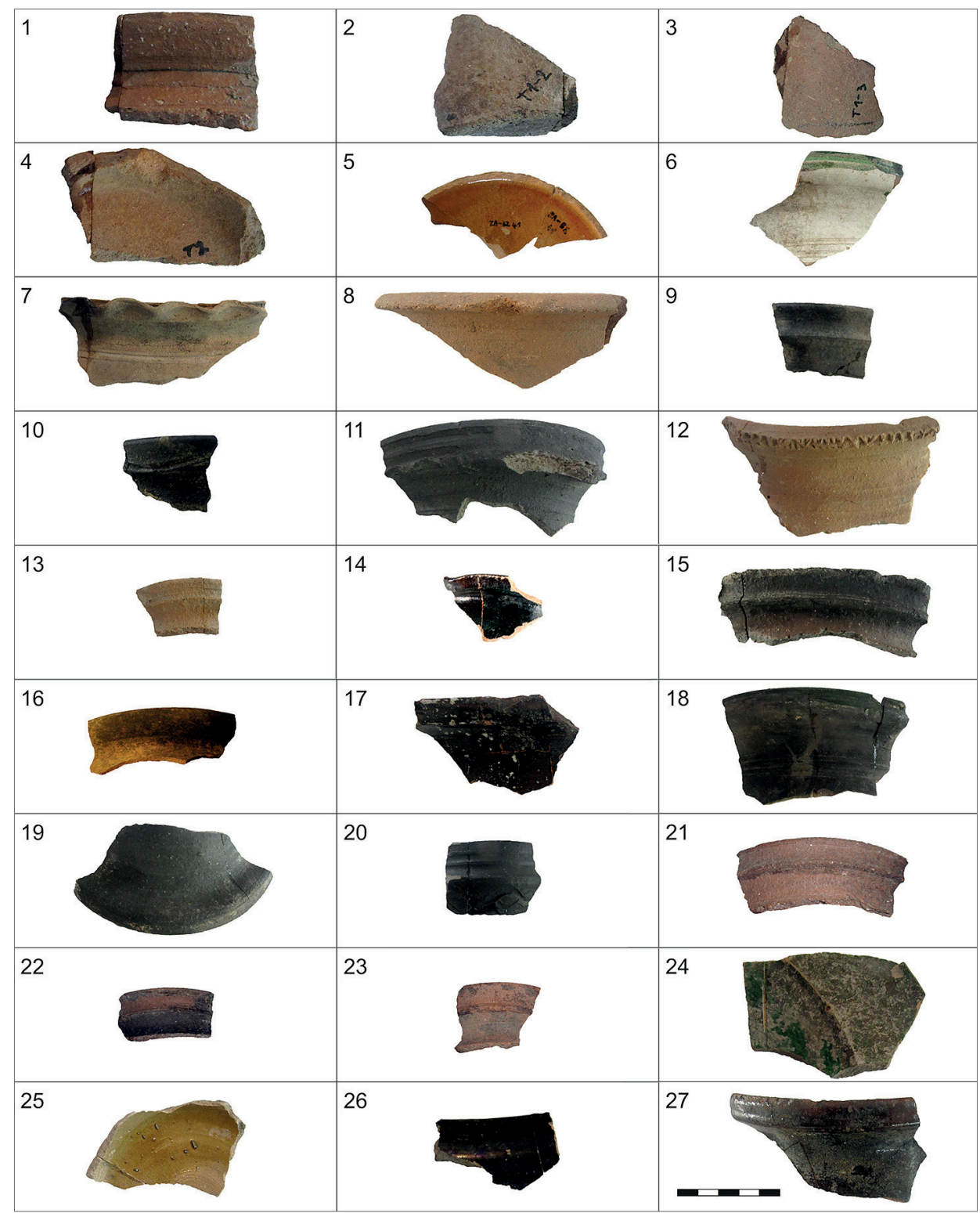

Obr. 3. Fotodokumentace studované keramiky. Keramická tř́ída 1 - vz. 1, 2, 3, 8 a 15; keramická třída 2 - vz. 4, 9, 12, 13, 21, 22, 23; keramická tř́́da 3 - vz. 5, 6, 7, 14, 16, 17, 18, 24, 25, 26, 27; keramická tř́́da 10 - vz. 10, 11, 19, 20.

Abb. 3. Fotodokumentation der untersuchten Keramik. Keramikklasse 1-Proben 1, 2, 3, 8 und 15; Keramikklasse 2 - Proben 4, 9, 12, 13, 21, 22, 23; Keramikklasse 3 - Proben 5, 6, 7, 14, 16, 17, 18, 24, 25, 26, 27; Keramikklasse 10 - Proben 10, 11, $19,2$.

palatína, jde tedy o prestižní lokalitu. Z písemných pramenů víme, že Turzové hrad minimálně do poloviny 17. století opakovaně obývali (Kurucárová 2012, 234; Šimkovic 2014, 25).

Vybrané vzorky reprezentují hlavní keramické třídy vyskytující se v raném novověku na území severozápadního Slovenska (Španihel 2014, 144, tab. 1). Keramická třída T1 představuje oxidačně pálené zboží, které bylo využíváno v regionu již od vrcholného středověku. Nachází 
se zejména $v$ kontextech 14. století. Během tohoto období náleží této keramické třídě prakticky všechny typy nádob. V pozdějším období ztrácí své dominantní postavení, ale stále se z ní vyrábí zadělávací mísy, hrnce jednodušší profilace a kachle. V novověku se z ní vyrábí jenom zadělávací mísy, které jsou ojediněle zevnitř natřené bílou hlinkou. Používání glazur nebo hlinek jiné barvy není v regionu doloženo. Výjimku tvoří samozřejmě kachle.

Výrobky třídy T2 jsou též páleny oxidačně a byly používány zejména ve vrcholném a pozdním středověku. Pravděpodobně tvoří přechod mezi keramickými třídami T1 a T3. Morfologicky jde zejména o hrnce a kachle, méně jsou doloženy zadělávací mísy a pokličky. Povrch nádob bývá glazovaný různobarevnou olověnou transparentní polevou a někdy i hlinkou.

Další oxidačně vypalované zboží třídy T3 tvoří dominantní složku novověké keramiky. Objevuje se již v pozdním středověku, ale vůdčí pozici získává až v tzv. přechodném období na počátku raného novověku. Zastoupeny jsou všechny druhy kuchyňské a stolní keramiky, výjimku tvoří zadělávací mísa. Povrch je upraven různobarevnými hlinkami a olověnou transparentní glazurou.

Třída T10 představuje v regionu nejrozšsiřenější redukčně vypalovanou keramiku, která je ekvivalentem třídy T2. Její používání se klade hlavně do pozdního středověku. Typickými nádobami jsou poháry a zvoncovité pokličky, méně džbány a kahany.

Pro možné určení zdrojů keramické suroviny byly získány vzorky ze dvou lokalit zmiňovaných v písemných pramenech jako hliníky - Trnové - Hrnčiarsky vrch, Bytčica - Hlinisko a dále pak fluviální sediment hlavního říčního toku v oblasti, Váhu.

Jedenáct vzorků bylo vybráno pro mikropetrografický popis (též OM - optická mikroskopie). Tyto vzorky byly upraveny do podoby mikropetrografických výbrusů a zdokumentovány v procházejícím polarizovaném světle. Pro jejich popis byl použit upravený systém P. Quinna (2013) doplněný o některé termíny a metodické postupy M. Gregerové a kol. (2010).

Analýza chemického složení byla provedena na práškových vzorcích v podobě lisovaných tablet pomocí energiově disperzního rtg. fluorescenčního spektrometru (ED-XRF) Rigaku NexCG. Př́stroj disponuje Pd anodou o výkonu $50 \mathrm{~W}$ a SSD detektorem s rozlišením do $145 \mathrm{eV}$. Pro lepší poměr signal-to-noise využívá nepřímé excitace pomocí sekundárních terčíků. Délka měření činila 120 sekund na každý terčík. Glazované keramické vzorky byly před mletím glazury zbaveny obrušováním povrchu, tak aby nebylo chemické složení keramické hmoty glazurou kontaminováno. Při analýze složení glazur byl měřen očištěný povrch keramického střepu. U sedmi vzorků bylo analyzováno složení glazur pomocí stejného ED-XRF spektrometru.

\section{Výsledky}

\subsection{Mikropetrografie}

Pomocí mikropetrografické analýzy bylo stanoveno zastoupení úlomků minerálů a hornin a byly popsány technologické znaky na keramice (tab. 2, 3). Podle jejich zastoupení byly vzorky metodou shlukové analýzy rozděleny do čtyř produkčních skupin - dále jen skupin (obr. 4 a 5). Takto zjištěné skupiny se mezi sebou liší z hlediska použité suroviny a technologie výroby.

\section{Skupina A}

Skupinu A tvoří vzorky 1, 2, 3 a 4. Jedná se o písčitou keramiku s vysokým obsahem neplastické složky. Vzhledem k faktu, že písčitých zrn je v keramické hmotě relativně více než zrn prachovitých, je možné usuzovat, že se jedná o záměrně přidávanou příměs, tedy ostřivo. Vzorky 1, 3 a 4 obsahují vyšší množství zrn prachové frakce a odlišují se tak od vzorku 2, který obsahuje převážně jen zrna písčité frakce a základní jílovitou hmotu. Tato variabilita může souviset s heterogenitou zdroje nebo právě s variabilitou ostření jílu. Keramika této skupiny je charakteristická vysokým obsahem úlomků živců a slíd. Ostřivo dále tvoří variabilní množství úlomků 
Tab. 2. Mikropetrografické semikvantitativní vyjádření zrnitosti s četností úlomků minerálů a hornin.

Tab. 2. Mikropetrographische semiquantitative Aussage der Körnung mit Häufigkeit von Mineral- und Gesteinsbruchstücken.

\begin{tabular}{|c|c|c|c|c|c|c|c|c|c|c|c|c|c|c|c|c|c|}
\hline 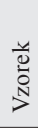 & 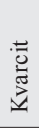 & $\stackrel{\frac{\pi}{3}}{\widetilde{\Omega}}$ & 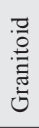 & $\begin{array}{l}0 \\
0 \\
0 \\
0 \\
0 \\
0 \\
0\end{array}$ & 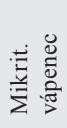 & 莺 & $\frac{\stackrel{\Xi}{N}}{\stackrel{D}{Z}}$ & 离 & 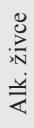 & $\begin{array}{l}\widehat{\widehat{a}} \\
\frac{\pi}{\frac{\pi}{0}} \\
\frac{0}{00} \\
\frac{\pi}{2}\end{array}$ & $\stackrel{\overline{0}}{0}$ & 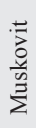 & $\begin{array}{l}\stackrel{\Xi}{\Xi} \\
\stackrel{\Xi}{\Xi} \\
\stackrel{\Xi}{\Xi}\end{array}$ & $\begin{array}{l}\overrightarrow{0} \\
\text { 를 } \\
\text { |1 }\end{array}$ & 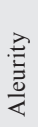 & 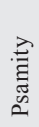 & $\begin{array}{l}\vec{D} \\
\text { D. } \\
\infty \\
\infty\end{array}$ \\
\hline 1 & 3 & 0 & 2 & 2 & 2 & 0 & 0 & 4 & 3 & 3 & 2 & 1 & 0 & 0 & 3 & 3 & 0 \\
\hline 2 & 3 & 0 & 4 & 2 & 0 & 2 & 0 & 3 & 4 & 3 & 2 & 0 & 0 & 0 & 0 & 4 & 1 \\
\hline 3 & 3 & 0 & 4 & 0 & 2 & 0 & 0 & 3 & 4 & 3 & 2 & 2 & 0 & 0 & 3 & 3 & 0 \\
\hline 4 & 3 & 0 & 2 & 0 & 0 & 1 & 0 & 5 & 2 & 0 & 5 & 3 & 1 & 0 & 2 & 4 & 0 \\
\hline 5 & 2 & 0 & 0 & 0 & 0 & 1 & 0 & 3 & 1 & 0 & 0 & 1 & 0 & 0 & 3 & 1 & 0 \\
\hline 6 & 2 & 0 & 0 & 0 & 0 & 1 & 0 & 3 & 0 & 0 & 0 & 2 & 0 & 0 & 4 & 2 & 0 \\
\hline 7 & 1 & 0 & 0 & 2 & 0 & 1 & 0 & 3 & 1 & 0 & 1 & 1 & 0 & 0 & 4 & 2 & 0 \\
\hline 8 & 3 & 1 & 2 & 3 & 3 & 2 & 0 & 3 & 2 & 3 & 2 & 2 & 0 & 1 & 3 & 3 & 0 \\
\hline 9 & 3 & 1 & 2 & 0 & 3 & 0 & 0 & 3 & 3 & 2 & 2 & 3 & 0 & 0 & 2 & 2 & 0 \\
\hline 10 & 2 & 1 & 2 & 1 & 2 & 0 & 1 & 3 & 3 & 2 & 2 & 2 & 0 & 0 & 3 & 2 & 0 \\
\hline 11 & 3 & 1 & 1 & 3 & 1 & 0 & 1 & 3 & 3 & 3 & 2 & 2 & 0 & 0 & 1 & 4 & 0 \\
\hline
\end{tabular}

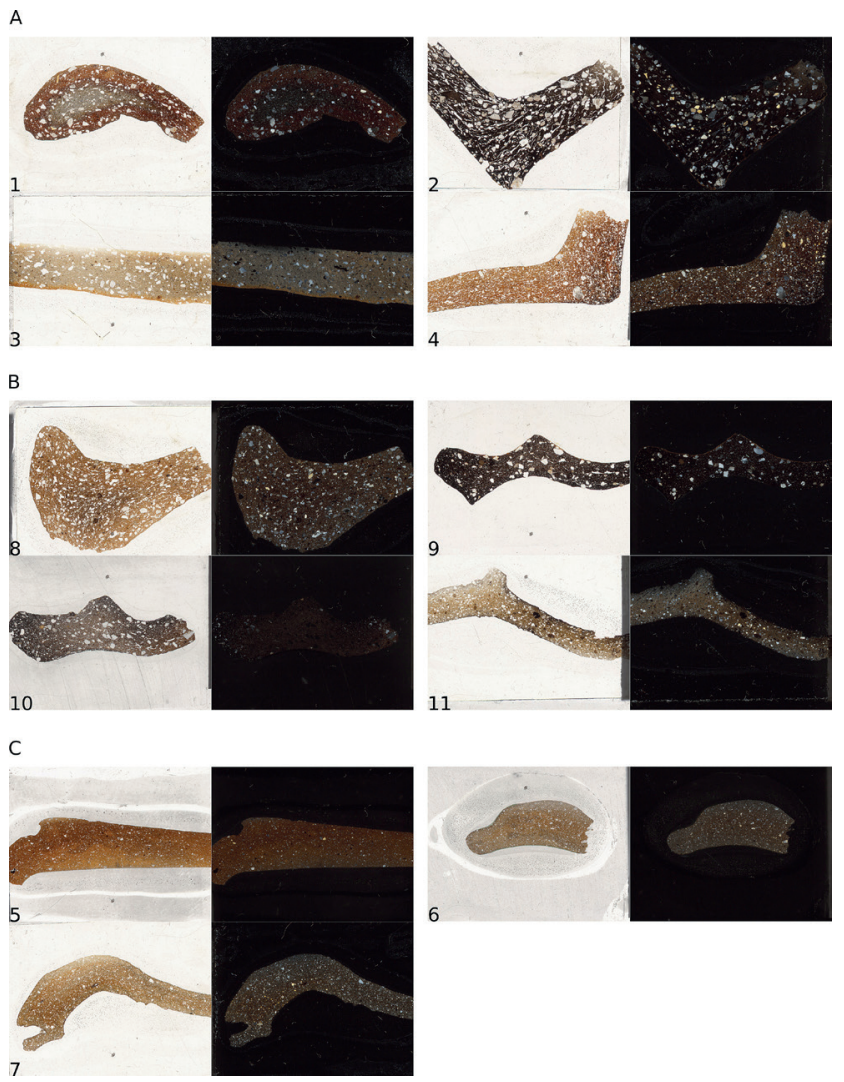

Obr. 4. Mikrofotodokumentace vzorků roztříděných do produkěních skupin (vlevo PPL, vpravo XPL).

Abb. 4. Mikrofotodokumentation der in Produktionsgruppen eingeteilten Proben (links PPL, rechts XPL). 
Tab. 3. Mikrostrukturní a mikromorfologické charakteristiky vzorků. Barvy stanoveny podle Munsellovy škály. Intenzita výpalu: 3 - střední. Vitrifikace matrix: + - lokálně kolem pórů. Charakter výpalu: o- oxidační, $\mathbf{r}$ - redukění, ro - kombinovaný. Rozestup zrn: - - zrna se dotýkají, + - vzájemná vzdálenost mezi zrny odpovídá velikosti zrn, ++ - zrna jsou od sebe vzdálena na velikost dvou zrn, +++- zrna jsou od sebe vzdálena na velikost mnoha zrn.

Tab. 3. Mikrostrukturelle und mikromorphologische Charakteristik der Proben. Farbenbestimmung nach Munsell-Farbsystem. Intensität des Brandes: 3 - mittel. Vitrifikation Matrix: + - lokal um die Poren. Charakter des Brandes: o- oxidierend, r-reduzierend, ro - kombiniert. Abstand der Körner: - - die Körner berühren sich, +- der Abstand zwischen den Körnern entspricht der Körnergröße, ++ - die Körner sind in der Größe von zwei Körnern voneinander entfernt, +++ - die Körner sind in der Entfernung von vielen Körnern voneinander entfernt.

\begin{tabular}{|c|c|c|c|c|c|c|c|c|c|c|c|c|c|c|c|c|c|c|c|}
\hline 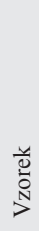 & $\begin{array}{l}\stackrel{\pi}{\Xi} \\
\stackrel{\Xi}{\Xi} \\
\frac{\tilde{\sigma}}{\omega}\end{array}$ & 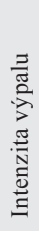 & 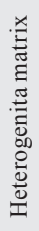 & 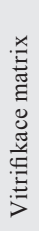 & 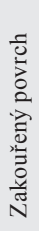 & 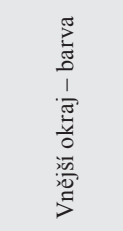 & 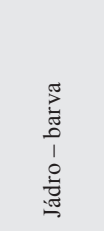 & 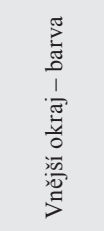 & 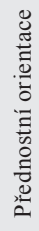 & 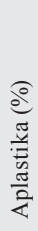 & 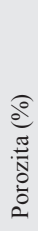 & 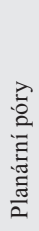 & 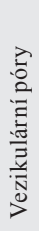 & 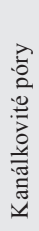 & 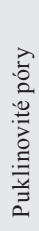 & $\begin{array}{l}\text { ते } \\
0 \\
0 \\
0 \\
0 \\
0 \\
0 \\
0 \\
0 \\
0 \\
0 \\
0\end{array}$ & 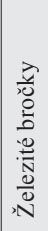 & 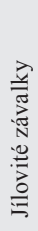 & 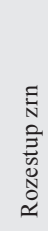 \\
\hline 1 & A & 3 & + & - & - & $\begin{array}{c}\text { o }(2.5 \mathrm{YR} \\
4 / 8)\end{array}$ & $\begin{array}{c}\mathrm{r}(7.5 \mathrm{YR} \\
2.5 / 3)\end{array}$ & $\begin{array}{c}\text { o }(2.5 \mathrm{YR} \\
4 / 8)\end{array}$ & ++ & 40 & 15 & + & - & - & - & - & + & + & + \\
\hline 2 & A & 3 & + & - & - & $\begin{array}{c}\mathrm{r}(10 \mathrm{YR} \\
2 / 1)\end{array}$ & & & ++ & 45 & 25 & + & - & - & - & - & $?$ & + & - \\
\hline 3 & A & 3 & + & - & - & $\begin{array}{c}\text { o }(2.5 \mathrm{YR} \\
4 / 8)\end{array}$ & $\begin{array}{c}\text { o (5YR } \\
2,5 / 2)\end{array}$ & $\begin{array}{c}\text { o }(2.5 \mathrm{YR} \\
4 / 8)\end{array}$ & - & 40 & 15 & - & + & - & - & + & ++ & - & +++ \\
\hline 4 & A & 3 & - & - & - & $\begin{array}{c}\mathrm{o}(2.5 \mathrm{YR} \\
4 / 8)\end{array}$ & $\begin{array}{c}\text { o }(2.5 \mathrm{YR} \\
4 / 8)\end{array}$ & $\begin{array}{c}\text { o }(2.5 \mathrm{YR} \\
4 / 8)\end{array}$ & ++ & 50 & 20 & + & - & - & - & - & - & - & - \\
\hline 5 & $\mathrm{C}$ & 3 & - & - & - & o 5 YR $4 / 8$ & & & ++ & 35 & 15 & + & + & - & - & + & + & - & ++ \\
\hline 6 & C & 3 & - & - & - & $\begin{array}{c}\text { o }(10 \mathrm{YR} \\
5 / 8- \\
7.5 \mathrm{YR} 5 / 8)\end{array}$ & & & + & 40 & 15 & + & + & - & - & + & + & - & + \\
\hline 7 & $\mathrm{C}$ & $3+$ & - & + & - & $\begin{array}{c}\text { o }(10 \mathrm{YR} \\
5 / 8- \\
7.5 \mathrm{YR} 5 / 8)\end{array}$ & & & + & 40 & 15 & + & + & - & - & + & + & - & + \\
\hline 8 & B & 3 & - & - & - & $\begin{array}{c}\text { o }(2.5 \mathrm{YR} \\
4 / 8)\end{array}$ & & & ++ & 40 & 15 & + & - & - & - & + & ++ & + & + \\
\hline 9 & B & 3 & - & - & - & $\begin{array}{c}\mathrm{r}(10 \mathrm{YR} \\
2 / 1)\end{array}$ & & & ++ & 35 & 10 & + & - & - & - & - & ? & + & ++ \\
\hline 10 & B & 3 & - & - & + & $\begin{array}{c}\text { ro }(10 \mathrm{YR} \\
3 / 2-10 \mathrm{YR} \\
2 / 2)\end{array}$ & & & + & 30 & 20 & + & + & - & - & - & ? & + & ++ \\
\hline 11 & B & 3 & + & - & + & $\begin{array}{c}\mathrm{o}(5 \mathrm{YR} \\
2,5 / 2)\end{array}$ & & & - & 40 & 15 & - & + & - & - & + & ++ & + & +++ \\
\hline
\end{tabular}

granitoidních hornin, pískovce, jílovce, mikritického vápence, ve všech vzorcích je stabilní zastoupení metakvarcitů, a stopové množství rohovce/silicitu. Vzorek 4 se od ostatních odlišuje vyšším obsahem slíd v základní hmotě a stopovým zastoupením sillimanitu.

Vzorky této skupiny nenesou jednotné znaky atmosféry výpalu. Vzorky 1, 3 a 4 mají oxidační okraje, kdežto vzorek 1 má navíc patrné redukční jádro. Vzorek 2 nese znaky redukčního prostředí jak v jádře, tak na okrajích. Teplota výpalu se mohla pohybovat zhruba mezi 750 a $1000{ }^{\circ} \mathrm{C}$ (biotit ztrácí pleochroismus, ale matrix ještě není vitrifikovaná). Keramika této produkční skupiny je barevně heterogenní. V prostředí oxidačního výpalu převládá červená barva $(2.5 \mathrm{YR} 4 / 8)$. V redukčním prostředí převažují odstíny $10 \mathrm{YR} 2 / 1$. Základní hmota není homogenizovaná. Vzorek 3 má odlišný typ pórů: drobné bublinky (vesicles) a komůrky. To svědčí o poněkud odlišné formovací technice, případně také o jiných fyzikálních vlastnostech hrnčířské suroviny. Vzorek 3 se dále odlišuje přítomností železitých závalků a většími rozestupy mezi zrny neplastické složky. Zastoupení neplastické složky je u všech vzorků podobné a činí 40-50 \%. 


\section{Cluster Dendrogram}

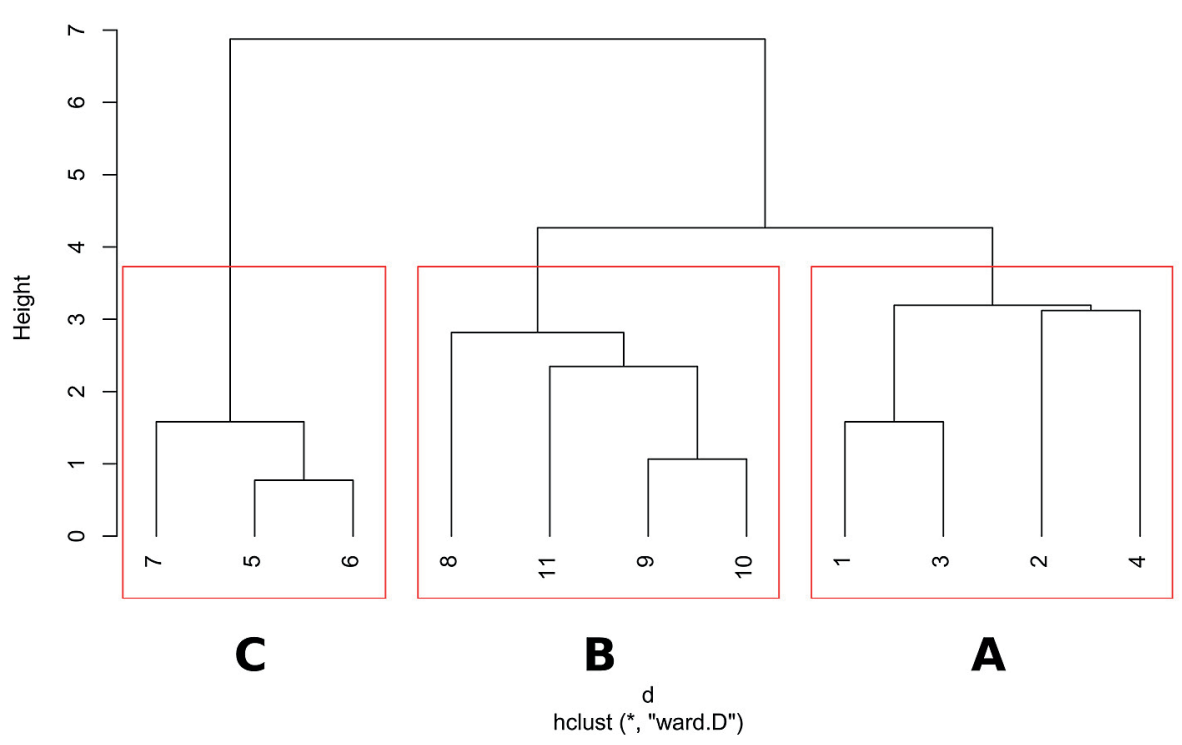

Obr. 5. Výsledek shlukové analýzy provedené na semikvantitativním zastoupení úlomků minerálů a hornin (tab. 2).

Abb. 5. Ergebnis der am semiquantitativen Vorkommen von Mineral- und Gesteinsbruchstücken durchgeführten Clusteranalyse (Tab. 2).

Zastoupení viditelných pórů je 15-25\%. Tuto provenienční skupinu lze tedy na základě zrnitosti, barvy matrix a morfologie i orientaci pórů označit za heterogenní skupinu.

\section{Skupina B}

Skupina B se skládá ze vzorků 8, 9, 10 a 11. Keramika skupiny B je písčitá, ale obsahuje menší množství pískových zrn než keramika skupiny A. Jako ostřivo posloužily úlomky metakvarcitů, mikritického vápence, pískovce, jílovce, granitoidních hornin, v malém množství byly identifikovány úlomky metamorfních hornin, silicitu a stopově andezitu. Úlomky minerálů jsou zastoupeny středním množstvím křemene, živců i slíd. Ve vzorku 8 byl rozpoznán zlomek epidotu.

Intenzita výpalu je stejná jako v prŕípadě předchozí skupiny, atmosféra je též variabilní - oxidační (vzorek 8, červená barva 2.5YR 4/8) přes redukčně oxidační (vzorek 10, barva velmi tmavě hnědá 10YR 3/2 - 10YR 2/2) až po redukční (vzorek 9, barva černá 10YR 2/1). Vzorek 11 nese znaky redukčního prostředí pouze na samém povrchu, což může souviset s tzv. zakuřováním (Čapek et al. 2018), barva jeho jádra je tmavě červenohnědá (5YR 2,5/2). Dle morfologie a orientace pórů lze předpokládat, že formovací technika a fyzikální vlastnosti hlíny byly u všech vzorků podobné. Ve všech případech kromě vzorku 11 se objevují planární póry, které indikují rychlý rotační pohyb. Vzorek 11 má odlišný typ pórů: drobné bublinky (vesicles) a komůrky. Zastoupení železitých závalků nelze u redukčně pálené keramiky stanovit. Rozestup neplastických zrn je na vzdálenost velikosti jednoho až dvou zrn. Zastoupení aplastik je 30-40\% a zastoupení viditelných pórů 15-20\%. Technologicko-strukturní charakteristiky nejsou v rozporu s mineralogicko-petrografickým rozdělením, přestože keramika působí makroskopicky různorodě. Vzorek 10 má na 
povrchu vrstvu organické hmoty, pravděpodobně jde o bitumen - ložisko př́rodního asfaltu se nachází v Nezbudskej Lúčke, přibližně 10 km jihovýchodně od centra Žiliny (Vangel-Decký-Remišová 2007, 102-108).

\section{Skupina C}

Skupinu C představují vzorky 5, 6 a 7. Vzorky této skupiny jsou relativně jemnozrnné, s vyšším obsahem prachovité než písčité frakce. Je pravděpodobné, že keramická surovina nebyla vůbec ostřena nebo byl přídavek ostřiva pouze marginální. Neplastickou složku tvoří menší množství úlomků metakvarcitu, silicitu a u vzorku 7 pískovce. Vzorek 5 obsahuje úlomek granitoidní horniny. $\mathrm{Z}$ úlomků minerálů je běžně zastoupen křemen. Ostatní minerály se vyskytují stopově alkalické živce a muskovit v převaze nad biotitem.

Intenzita výpalu je stejná jako v př́ípadě předchozích skupin. Výjimkou je vzorek 7 , který jeví známky vitrifikace základní hmoty, což naznačuje vyšší intenzitu výpalu. Výpal proběhl ve všech případech v oxidačním prostředí, čemuž odpovídá také barva žlutočervená 5 YR 4/8 (vzorek 5) a žlutohnědá až hnědá 10YR 5/8-7.5YR 5/8 (vzorky 6 a 7). Póry a zrna jsou paralelně orientované. Vyskytují se planární póry svědčící o rychlém rotačním pohybu, bublinky i komůrky. Ve všech vzorcích jsou viditelné závalky oxidů železa, zatímco jílovité závalky nebyly zaznamenány. Zastoupení aplastik je 35-40 \% a zastoupení viditelných pórů je u všech vzorků stanoveno na $15 \%$.

\subsection{ED-XRF keramické hmoty}

Chemické prvky (tab. 4) odlišující mikropetrografické skupiny byly identifikovány klasifikačním stromem z knihovny rpart ve statistickém programu R (R Core Team, 2014, Therneau-Atkinson 2019). Podle klasifikačního stromu lze produkční skupiny vymezit na základě koncentrací Si a Al, případně poměru Si s $\mathrm{Al}$ a Ti (obr. 6). Tyto chemické prvky byly vybrány pro sestavení binárních diagramů, pomocí kterých lze vymezit jednotlivé skupiny a také srovnat jejich postavení se zdroji

A

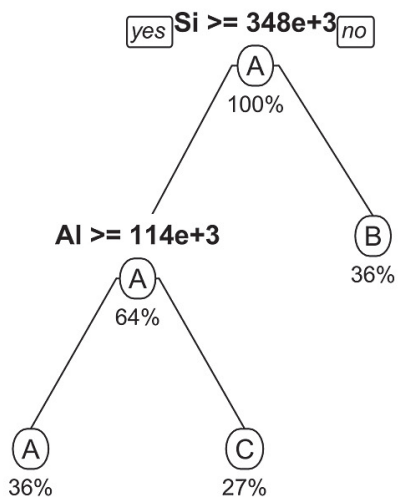

B

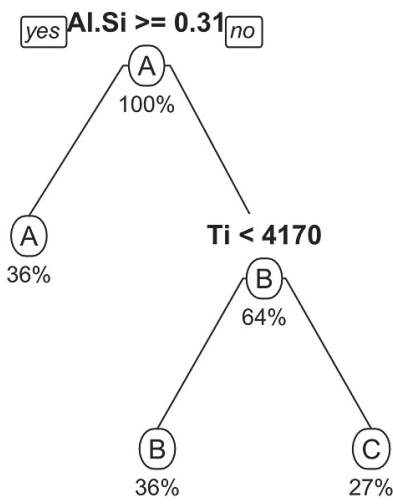

Obr. 6. Klasifikační stromy mikropetrografických skupin podle jejich chemického složení. 

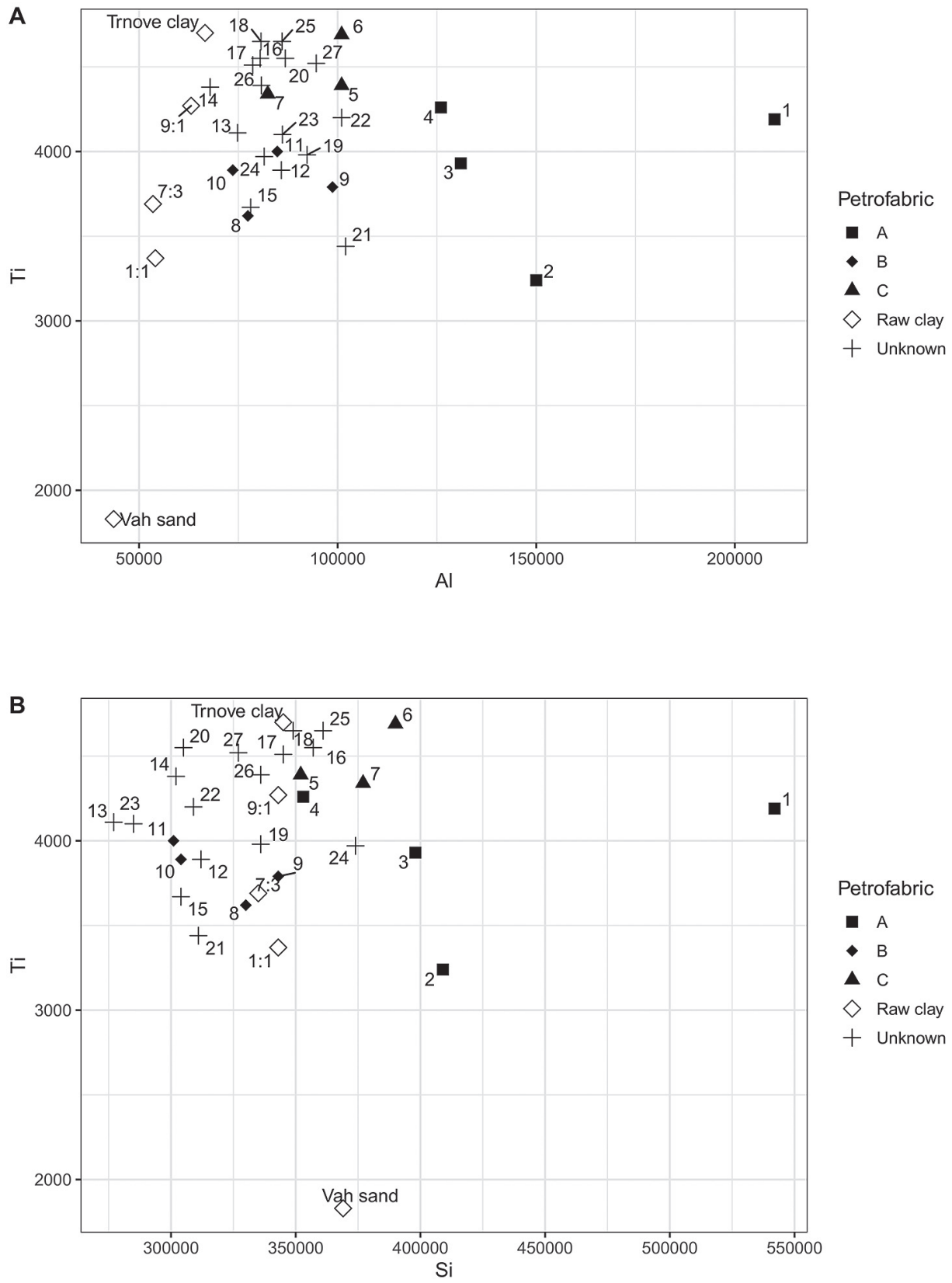

Obr. 7. Binární diagramy znázorňující poměry koncentrací vybraných prvků vzhledem k mikropetrografickým skupinám A: poměry $\mathrm{Al}$ a $\mathrm{Ti}$; $\mathrm{B}$ : poměry $\mathrm{Si}$ a $\mathrm{Ti}$.

Abb. 7. Binärdiagramme zur Veranschaulichung der Verhältnisse der Konzentrationen ausgewählter Elemente im Hinblick auf mikropetrographische Gruppen - A: Verhältnisse Al und Ti; B: Verhältnisse Si und Ti. 


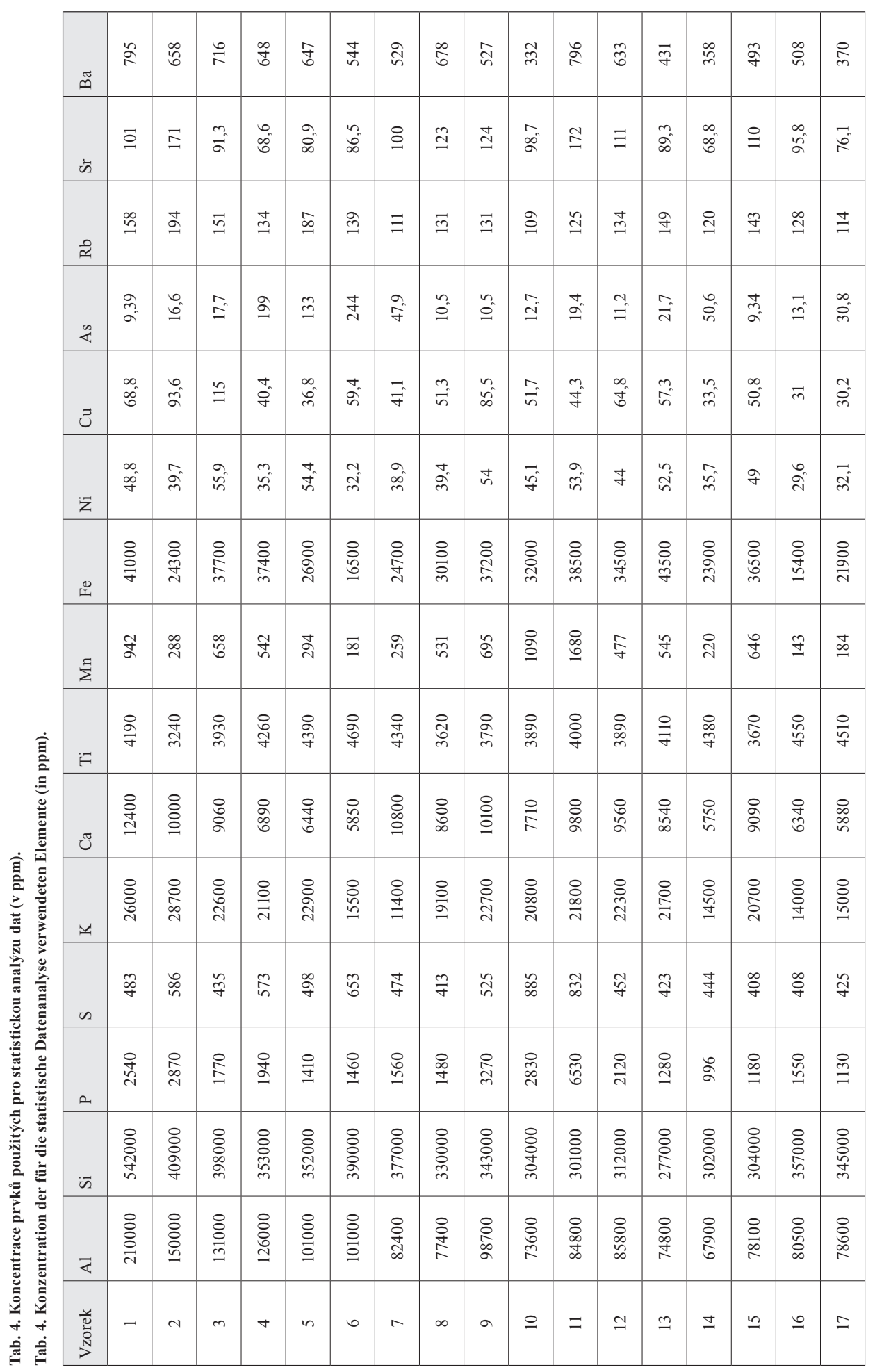




\begin{tabular}{|c|c|c|c|c|c|c|c|c|c|c|c|c|c|c|c|c|c|c|}
\hline 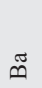 & o్ & $\tilde{b}$ & สี & in & 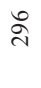 & $\vec{D}$ & $\stackrel{\text { I }}{\mathrm{N}}$ & in & $\vec{n}$ & $\stackrel{\text { o }}{+}$ & $\underset{\infty}{+}$ & iq & & $\underset{\infty}{\vec{F}}$ & 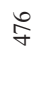 & f & $\vec{r}$ & $\ddot{\gamma}$ \\
\hline$\dot{n}$ & $\hat{\otimes}$ & $\hat{m}$ & $\stackrel{\varrho}{=}$ & ले & $\begin{array}{l}\text { के } \\
\text { in }\end{array}$ & $\begin{array}{l}0 \\
\infty_{0}^{\circ}\end{array}$ & $\stackrel{m}{\stackrel{\infty}{\infty}}$ & 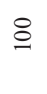 & $\hat{\imath}$ & $\stackrel{+}{\circ}$ & $\begin{array}{l}n \\
\stackrel{\infty}{\infty}\end{array}$ & $\begin{array}{l}0 \\
\stackrel{0}{0}\end{array}$ & 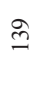 & $\cong$ & 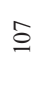 & $\begin{array}{l}0 \\
\frac{1}{\infty}\end{array}$ & $\begin{array}{l}0 \\
\infty \\
\infty\end{array}$ & $\stackrel{m}{\infty}^{2}$ \\
\hline ๙ิ & $\tilde{\Xi}$ & $\Xi$ & 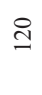 & $\stackrel{\infty}{=}$ & $\stackrel{\varrho}{=}$ & $\stackrel{\text { Iq }}{ \pm}$ & $\stackrel{\cong}{\Xi}$ & $\stackrel{\infty}{\underline{n}}$ & $\hat{n}$ & $\stackrel{\infty}{\stackrel{\infty}{\sim}}$ & $\stackrel{\circ}{ }$ & $\vec{\Xi}$ & ते & $\begin{array}{l}n \\
\infty_{0}^{n} \\
\stackrel{n}{n}\end{array}$ & $\begin{array}{l}n \\
\stackrel{f}{f}\end{array}$ & $\stackrel{+}{\infty} \underset{\infty}{0}$ & 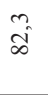 & $\begin{array}{l}\stackrel{0}{\wedge} \\
\stackrel{1}{*}\end{array}$ \\
\hline 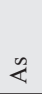 & $\underset{m}{\stackrel{+}{m}}$ & $\hat{m}$ & $\underline{\hat{\sigma}}$ & 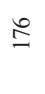 & $\stackrel{+}{8}$ & 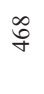 & $\bar{\beth}$ & $\overrightarrow{0}$ & $\vec{n}$ & $\hat{\widetilde{q}}$ & $\stackrel{\curvearrowright}{\varrho}$ & $\stackrel{\Omega}{\circ}$ & $\vec{\sigma}$ & $\stackrel{+}{\stackrel{5}{n}}$ & $\begin{array}{l}\stackrel{n}{\alpha} \\
\ddot{n}\end{array}$ & $\hat{a}$ & $\begin{array}{c}m \\
m \\
\infty\end{array}$ & $\underset{\infty}{ \pm}$ \\
\hline$\Xi$ & $\tilde{n}$ & $\stackrel{m}{i}$ & $\underset{⿱}{+}$ & ले & $\tilde{m}$ & $\stackrel{\infty}{\infty}$ & $\begin{array}{l}\stackrel{f}{f} \\
\text { f }\end{array}$ & $\overrightarrow{\mathrm{f}}$ & $\begin{array}{l}0 \\
\dot{f}\end{array}$ & $\begin{array}{l}\text { Oे } \\
\dot{m}\end{array}$ & बें & $\begin{array}{l}\infty \\
\stackrel{\sim}{\sim}\end{array}$ & $\begin{array}{l}\stackrel{0}{0} \\
\infty\end{array}$ & $\hat{\infty}$ & 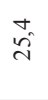 & $\overrightarrow{\vec{N}}$ & ठ̊ & के \\
\hline$\ddot{z}$ & 仓े & $\stackrel{+}{a}$ & $\vec{i}$ & $\stackrel{i}{~}$ & $\begin{array}{l}\infty \\
\text { in } \\
\text { nd }\end{array}$ & $\begin{array}{l}\stackrel{N}{~} \\
\stackrel{m}{ }\end{array}$ & $\vec{m}$ & 户े & $\begin{array}{l}\infty \\
\text { i } \\
\text { m }\end{array}$ & $\begin{array}{l}0 \\
\text { in }\end{array}$ & $\hat{n}^{2}$ & $\stackrel{+}{a}$ & $\stackrel{2}{\cong}$ & $\begin{array}{l}n \\
\infty\end{array}$ & ठे & $\stackrel{+}{\stackrel{+}{d}}$ & $\begin{array}{l}n \\
\stackrel{n}{d}\end{array}$ & $\begin{array}{l}\infty \\
\stackrel{+}{d}\end{array}$ \\
\hline I. & $\begin{array}{l}\stackrel{+}{+} \\
\stackrel{+}{+}\end{array}$ & $\begin{array}{l}\text { \& } \\
\text { C. }\end{array}$ & $\begin{array}{l}\text { \& } \\
\text { ల్ల }\end{array}$ & $\begin{array}{l}\stackrel{0}{\infty} \\
\underset{\sim}{2}\end{array}$ & $\frac{8}{\stackrel{8}{0}}$ & $\begin{array}{l}\stackrel{\circ}{\infty} \\
\stackrel{\infty}{m}\end{array}$ & $\frac{\stackrel{8}{+}}{\stackrel{8}{+}}$ & $\underset{i}{\stackrel{2}{2}}$ & $\begin{array}{l}\stackrel{8}{\circ} \\
\stackrel{\text { ̀े }}{2}\end{array}$ & $\underset{m}{\stackrel{\circ}{二}}$ & $\begin{array}{l}\text { ¿े } \\
\text { ते }\end{array}$ & $\begin{array}{l}\stackrel{+}{9} \\
\stackrel{+}{9}\end{array}$ & $\begin{array}{l}\stackrel{ั}{I} \\
\text { İ }\end{array}$ & $\begin{array}{l}\text { \&े } \\
\text { ల్ }\end{array}$ & $\begin{array}{l}8 \\
\vdots \\
\vdots \\
\end{array}$ & $\underset{\mathrm{N}}{\stackrel{\Xi}{\mathrm{N}}}$ & $\begin{array}{l}\stackrel{8}{ } \\
\stackrel{+}{9}\end{array}$ & $\begin{array}{l}\stackrel{్}{1} \\
\text { }\end{array}$ \\
\hline$\Sigma^{E}$ & $\stackrel{\infty}{\infty}$ & $\stackrel{\infty}{\infty}$ & $\frac{n}{N}$ & $\underset{\sim}{\infty}$ & $\stackrel{\tilde{f}}{+}$ & 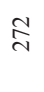 & $\underline{\underline{0}}$ & $\underline{\infty}$ & $\cong$ & $\underset{\sim}{\mathbb{N}}$ & d & $\stackrel{\text { In }}{\mathrm{n}}$ & $\tilde{q}$ & $\stackrel{\stackrel{\sim}{\sim}}{.}$ & 点 & $\frac{m}{6}$ & $\stackrel{\infty}{\stackrel{d}{n}}$ & \\
\hline$\ddot{F}$ & है & $\begin{array}{l}\stackrel{\infty}{\circ} \\
\text { d) }\end{array}$ & 号 & 亭 & 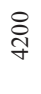 & $\stackrel{\circ}{\circ}$ & 尽 & $\begin{array}{l}8 \\
b \\
b\end{array}$ & $\stackrel{\text { ণ }}{\stackrel{一}{ }}$ & $\begin{array}{l}\text { ָे } \\
\text { r }\end{array}$ & 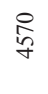 & 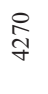 & 尽 & $\underset{d}{\stackrel{+}{2}}$ & 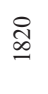 & 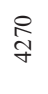 & 各 & $\underset{m}{\stackrel{R}{m}}$ \\
\hline$\tilde{U}$ & $\stackrel{\circ}{8}$ & 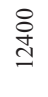 & ๙్ల & ஜ̊ & $\begin{array}{l}\text { Iิ } \\
\text { }\end{array}$ & 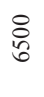 & 尽 & 옹 & $\begin{array}{l}8 \\
\text { in }\end{array}$ & $\begin{array}{l}\infty \\
\infty \\
\infty \\
0\end{array}$ & $\begin{array}{l}\text { ஜ } \\
\dot{q}\end{array}$ & 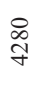 & 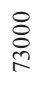 & $\begin{array}{l}\stackrel{8}{9} \\
\text { in } \\
\text { in }\end{array}$ & $\underset{\stackrel{\infty}{\infty}}{\stackrel{\Xi}{\infty}}$ & 命 & $\stackrel{\circ}{\circ}$ & ஃ̊ㅇ \\
\hline$\searrow$ & 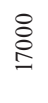 & $\frac{\stackrel{+}{+}}{\sim}$ & ষ্ণ & $\begin{array}{l}\stackrel{8}{\infty} \\
\stackrel{\infty}{N}\end{array}$ & $\begin{array}{l}\text { ¿ें } \\
\text { ते }\end{array}$ & $\begin{array}{l}\stackrel{8}{\infty} \\
\stackrel{\infty}{N}\end{array}$ & 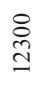 & $\frac{\circ}{n}$ & 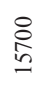 & 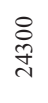 & $\begin{array}{l}\stackrel{8}{o} \\
\stackrel{9}{2}\end{array}$ & 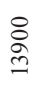 & $\begin{array}{l}\stackrel{0}{ળ} \\
\text { I }\end{array}$ & $\begin{array}{l}\stackrel{8}{0} \\
\stackrel{0}{=}\end{array}$ & $\frac{2}{n}$ & $\frac{8}{n}$ & 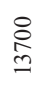 & 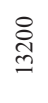 \\
\hline$n$ & \&̊a & $\vec{n}$ & $\tilde{\delta}$ & $\frac{n}{6}$ & $\stackrel{g}{q}$ & $\underset{Z}{\stackrel{J}{*}}$ & $\underset{\mathscr{f}}{\stackrel{\alpha}{f}}$ & $\underset{\sim}{\sim}$ & $\stackrel{\infty}{\underset{f}{f}}$ & $\stackrel{\widetilde{f}}{\widetilde{f}}$ & $\hat{\tilde{f}}$ & ț & के & 总 & $\bar{\sigma}$ & 茓 & 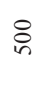 & $\stackrel{\circ}{n}$ \\
\hline$a$ & 기 & 㝒 & ঙ․ & $\underset{\infty}{\stackrel{0}{\infty}}$ & 号 & $\stackrel{8}{\circ}$ & 导 & $\stackrel{\circ}{\circ}$ & $\stackrel{Ð}{\ni}$ & 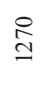 & 导 & $\underset{\infty}{\stackrel{\leftrightarrow}{*}}$ & $\stackrel{\circ}{\stackrel{\circ}{\varrho}}$ & 导 & 号 & స్లి & $\stackrel{\text { ป }}{=}$ & $\stackrel{\circ}{\underline{m}}$ \\
\hline$\vec{n}$ & $\begin{array}{l}\stackrel{\circ}{\circ} \\
\text { 市 }\end{array}$ & $\begin{array}{l}\text { \& } \\
\text { d } \\
\text { m }\end{array}$ & $\begin{array}{l}\text { Oे } \\
\text { : } \\
\text { ò }\end{array}$ & $\underset{m}{\stackrel{\Xi}{\Rightarrow}}$ & $\begin{array}{l}\text { \& } \\
\text { ᄋे } \\
\text { ᄋे }\end{array}$ & 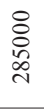 & 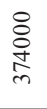 & $\frac{\stackrel{\Xi}{0}}{\stackrel{0}{0}}$ & $\begin{array}{l}\text { \& } \\
\text { ¿ } \\
\text { m }\end{array}$ & 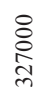 & 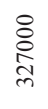 & $\begin{array}{l}\text { ¿े } \\
\text { ర్ర } \\
\text { i }\end{array}$ & 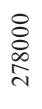 & $\begin{array}{l}\stackrel{8}{0} \\
\text { d. } \\
\text { ते }\end{array}$ & $\begin{array}{l}8 \\
\vdots \\
0 \\
n \\
n\end{array}$ & $\begin{array}{l}\stackrel{8}{0} \\
\text { fे } \\
\text { fे }\end{array}$ & 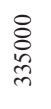 & $\begin{array}{l}\stackrel{8}{0} \\
\stackrel{\infty}{m}\end{array}$ \\
\hline ব & $\begin{array}{l}\stackrel{2}{2} \\
\vdots \\
\infty\end{array}$ & $\begin{array}{l}\text { ¿ } \\
\text { నू }\end{array}$ & $\begin{array}{l}8 \\
\stackrel{8}{0} \\
\infty\end{array}$ & $\begin{array}{l}8 \\
\stackrel{0}{0} \\
\text { O }\end{array}$ & $\begin{array}{l}\stackrel{8}{\circ} \\
\stackrel{0}{0}\end{array}$ & $\begin{array}{l}\stackrel{0}{0} \\
\stackrel{0}{\circ}\end{array}$ & $\stackrel{\substack{n \\
\infty}}{\frac{h}{\infty}}$ & $\begin{array}{l}\text { \& } \\
\text { ¿. } \\
\infty\end{array}$ & $\begin{array}{l}\stackrel{8}{0} \\
\stackrel{\infty}{\infty}\end{array}$ & 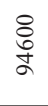 & $\begin{array}{l}8 \\
\stackrel{+}{+} \\
i \\
\infty\end{array}$ & $\begin{array}{l}\stackrel{\text { जे }}{\text { in }}\end{array}$ & $\frac{8}{n}$ & $\begin{array}{l}\text { ¿े } \\
\text { ñ } \\
\text { n. }\end{array}$ & 品 & $\frac{\stackrel{\circ}{3}}{30}$ & 怘 & 六 \\
\hline 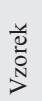 & $\stackrel{\infty}{\sim}$ & 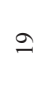 & ㄱ. & $\vec{\sim}$ & ส & $\tilde{\sim}$ & $\stackrel{\sim}{\sim}$ & $\ddot{\sim}$ & $\stackrel{\sim}{\sim}$ & $\bar{\imath}$ & $\stackrel{\infty}{\sim}$ & ते & ㅇ & $\vec{m}$ & లు & $\vec{\jmath}$ & $\stackrel{?}{l}_{t}^{\frac{r}{2}}$ & $\begin{array}{l}n \\
n \\
2\end{array}$ \\
\hline
\end{tabular}


potenciálních surovin (obr. 7, tab. 5, 6). Jako suroviny pro srovnání chemického složení byly použity vzorky z historického hliníku z lokality Trnové - Hrnčiarsky vrch a říčních písků Váhu a jejich směsi v poměrech $9: 1$, $7: 3$ a $1: 1$ pro možnost ověření ostření hlíny tímto materiálem. Vzorky ze skupiny $\mathrm{C}$ se shlukují okolo vzorku z hliníku v Trnovém. Ze statistického vyhodnocení byly vyřazeny vzorky z lokality Bytčica - Hlinisko z důvodu př́liš odlišného chemického složení vzhledem k ostatním vzorkům (zásadním rozdílem byl vysoký obsah Ca). Na finálním diagramu z koncentrací $\mathrm{Al} / \mathrm{Si}$ a Ti jsou vedle skupin vyneseny také ovály znázorňující jejich vymezení na základě klasifikace vzorků bez mikropetrografické analýzy na základě chemického složení prostřednictvím modelu podle druhého klasifikačního stromu z knihovny rpart (obr. 8). Interpretační diagram rovněž znázorňuje, jak jsou poměry vybraných chemických prvků u vzorků surovin a experimentálních vzorků ovlivňovány vzájemnými poměry.

\subsection{ED-XRF glazur}

U vybraných vzorků (tab. 7,8$)$ byla provedena analýza glazur pomocí stolního ED-XRF spektrometru. Výsledky jsou promítnuty do ternárního diagramu (obr. 9), který se používá pro klasifikaci chemického složení glazur (Tite et al. 1998). V našem př́ípadě se NAKCFM rovná $\mathrm{Na}+\mathrm{Al}+\mathrm{K}+\mathrm{Ca}+\mathrm{Fe}+\mathrm{Mg}$ (na rozdíl od citovaného zdroje nebyly použity koncentrace oxidů, ale přímo prvků). Ve všech případech se jedná o vysoce olovnaté glazury. Ve vzorcích mimo vzorek 5 byla detekována měd', která funguje jako zelené barvítko. Ve vzorcích 26 a 27 byl detekován mangan, který se projevuje načernalým zabarvením. Barva všech glazur je rovněž ovlivněna přítomností železa. Př́ítomnost oxidu $\mathrm{Al}_{2} \mathrm{O}_{3}$, jenž byl detekován ve čtyřech vzorcích $(5,6,17$ a 27), může mít dvě příčiny. První možností je, že glazovaná část stř̌epu nebyla dostatečně velká, a byl tedy analyzován i povrch nádoby mimo glazuru. Druhou možností je, že jako část suroviny pro glazuru byl použit jíl.

\section{Diskuse}

Určení provenience ostřiva pro skupinu A je založeno na přítomnosti písčité frakce složené převážně ze zaoblených klastů, které zahrnují také úlomky granitoidů. Velikost a tvar zrn i jejich petrografické a minerální složení odpovídají sedimentu uloženému v prostředí větší řeky. Granitoidy tvořící podstatnou část neplastické složky mají pravděpodobně původ $\mathrm{v}$ jaderných pohořích Západních Karpat, podobně jako vápence, které často tvoří jejich příkrovy. Klastické 
Tab. 6. Kontingenční tabulka znázorňující vztah klasifikačních tříd, skupin, keramických tvarů a lokalit.

Tab. 6. Kontingenztabelle mit Veranschaulichung der Beziehungen der Klassifizierungsklassen, Gruppen, Keramikformen und Fundstellen.

\begin{tabular}{|c|c|c|c|c|c|c|c|c|c|c|c|c|c|c|c|}
\hline & & \multicolumn{5}{|c|}{ Budatín } & \multicolumn{4}{|c|}{ Lietava } & \multicolumn{4}{|c|}{ Žilina } & \multirow[t]{2}{*}{ Suma } \\
\hline $\mathrm{KT}$ & Skupina & džbán & hrnec & z. m & $\mathrm{jd} / \mathrm{t}$ & Suma & hrnec & z. m & $\mathrm{jd} / \mathrm{t}$ & Suma & džbán & hrnec & poklice & Suma & \\
\hline \multirow[t]{3}{*}{ T1 } & & & 1 & 1 & & 2 & & 3 & & 3 & & & & & 5 \\
\hline & A & & & & & & & 3 & & 3 & & & & & 3 \\
\hline & B & & 1 & 1 & & 2 & & & & & & & & & 2 \\
\hline \multirow[t]{3}{*}{ T2 } & & & 3 & & & 3 & 4 & & & 4 & & & & & 7 \\
\hline & A & & & & & & 3 & & & 3 & & & & & 3 \\
\hline & B & & 3 & & & 3 & 1 & & & 1 & & & & & 4 \\
\hline \multirow[t]{3}{*}{ T3 } & & 1 & 3 & & 1 & 5 & 4 & & 1 & 5 & & 1 & & 1 & 11 \\
\hline & B & & & & & & & & 1 & 1 & & & & & 1 \\
\hline & $\mathrm{C}$ & 1 & 3 & & 1 & 5 & 4 & & & 4 & & 1 & & 1 & 10 \\
\hline \multirow[t]{3}{*}{ T10 } & & & & & & & & & & & 3 & & 1 & 4 & 4 \\
\hline & B & & & & & & & & & & 2 & & 1 & 3 & 3 \\
\hline & $\mathrm{C}$ & & & & & & & & & & 1 & & & 1 & 1 \\
\hline Suma & & 1 & 7 & 1 & 1 & 10 & 8 & 3 & 1 & 12 & 3 & 1 & 1 & 5 & 27 \\
\hline
\end{tabular}

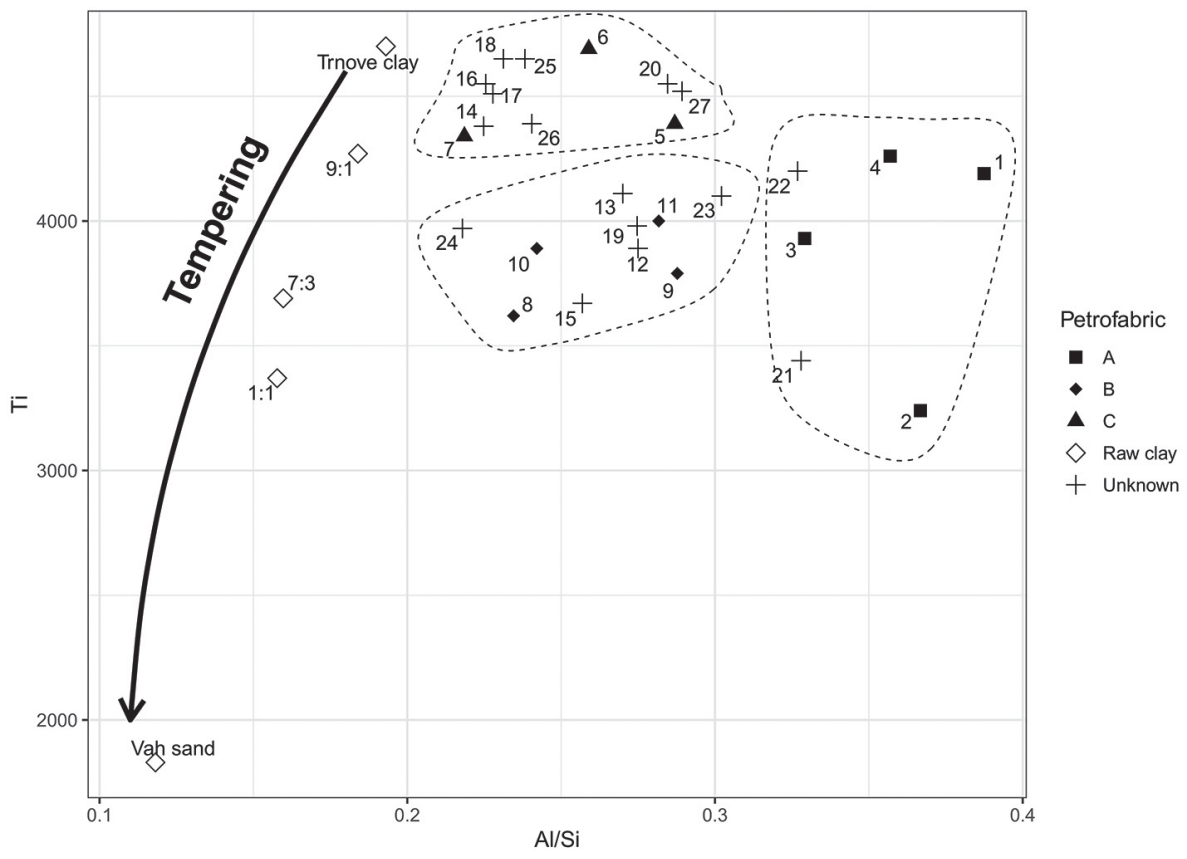

Obr. 8. Binární diagram znázorňující poměry Al/Si a Ti vzhledem k mikropetrografickým skupinám, potenciálním surovinám a jejich směsím. Hypotetický projev přidávání ostřiva do hlíny je znázorněn šipkou.

Abb. 8. Binärdiagramm zur Veranschaulichung der Verhältnisse Al/Si und Ti im Hinbick auf mikropetrographische Gruppen, potenzielle Rohstoffe und ihre Mischungen. Die hypothetische Erscheinung, dass dem Lehm ein Magerungsmittel beigegeben wurde, ist mit einem Pfeil dargestellt. 
sedimentární horniny mohou pocházet z bradlového pásma či z paleogenních sedimentů podtatranské skupiny. Bradlové pásmo leží u Žiliny na pravém břehu Váhu, severně a severovýchodně od města. Horniny odvozené $\mathrm{z}$ bradlového pásma přináší řeka Kysuca do toku Váhu, v němž se jejich úlomky mísí s fragmenty hornin zmíněnými výše. Ve vzorcích skupiny B byly oproti zástupcům skupiny A pozorovány úlomky metamorfovaných hornin, které se také nachází v krystaliniku jaderných pohoří. Keramika této skupiny je pravděpodobně rovněž lokálního původu. Skupina $\mathrm{C}$ představuje keramiku s jemnozrn-
Tab. 7. Makroskopické určení glazury.

Tab. 7. Makroskopische Glasurbestimmung.

\begin{tabular}{|c|c|}
\hline Vzorek & Makroskopické určení glazury \\
\hline 5 & bezbarevná olověná transparentní glazura \\
\hline 6 & zelená olověná transparentní glazura \\
\hline 17 -vnější & zelená olověná transparentní glazura \\
\hline 17 -vnitřní & zelená olověná transparentní glazura \\
\hline 18 & zelená olověná transparentní glazura \\
\hline 24 & zelená olověná transparentní glazura \\
\hline 25 & bezbarevná olověná transparentní glazura \\
\hline 26 & černá olověná transparentní glazura \\
\hline 27 & černá olověná transparentní glazura \\
\hline
\end{tabular}

Tab. 8. Koncentrace oxidů v glazurách.

Tab. 8. Koncentration der Oxide in den Glasuren.

\begin{tabular}{|c|c|c|c|c|c|c|c|c|c|c|}
\hline ID & $\mathrm{Na}_{2} \mathrm{O}$ & $\mathrm{MgO}$ & $\mathrm{Al}_{2} \mathrm{O}_{3}$ & $\mathrm{SiO}_{2}$ & $\mathrm{~K}_{2} \mathrm{O}$ & $\mathrm{CaO}$ & $\mathrm{MnO}$ & $\mathrm{Fe}_{2} \mathrm{O}_{3}$ & $\mathrm{CuO}$ & $\mathrm{PbO}$ \\
\hline 5 & 2,8 & 0,6 & 5,7 & 31,3 & 1,0 & 0,7 & 0,0 & 2,7 & 0,0 & 55,2 \\
\hline 6 & 3,0 & 0,0 & 4,2 & 28,4 & 0,5 & 0,7 & 0,0 & 2,2 & 2,4 & 58,6 \\
\hline 17 -vnější (17out) & 2,5 & 1,7 & 10,9 & 22,1 & 0,5 & 12,0 & 2,4 & 1,6 & 0,2 & 46,0 \\
\hline 17 -vnitřní (17in) & 2,9 & 1,4 & 0,0 & 23,3 & 0,8 & 11,4 & 0,0 & 1,1 & 0,1 & 59,0 \\
\hline 18 & 4,9 & 1,2 & 0,0 & 25,3 & 0,7 & 0,9 & 0,0 & 1,4 & 3,2 & 62,3 \\
\hline 24 & 1,2 & 1,6 & 0,0 & 39,5 & 0,6 & 1,8 & 0,0 & 1,5 & 2,1 & 51,7 \\
\hline 25 & 1,5 & 1,7 & 0,0 & 27,4 & 0,4 & 1,4 & 0,0 & 1,9 & 0,1 & 65,6 \\
\hline 26 & 3,0 & 1,4 & 0,0 & 19,9 & 0,4 & 1,0 & 1,3 & 1,3 & 2,1 & 69,5 \\
\hline 27 & 0,4 & 2,2 & 27,9 & 13,5 & 0,3 & 22,5 & 0,0 & 2,1 & 0,1 & 30,9 \\
\hline
\end{tabular}

nou matrix. Sporadicky se vyskytující zrna hornin omezují možnosti určení provenience, avšak podle jejich typů (pískovce, rohovec, granitoidy) není důvod hledat původ jinde než v údolí Váhu.

Použitím druhého modelu klasifikačního stromu (obr. 6) bylo možné přiřadit vzorky, které nebyly podrobeny mikropetrografickému rozboru, ke třem definovaným skupinám (A, B a C) a tuto klasifikaci následně konfrontovat s makroskopicky určenými tř́́dami, morfologií nádob a lokalitou jejich původu. $\mathrm{Z}$ interpretačního diagramu lze vyvodit, že pokud byly vzorky skupin B a C ze stejné hlíny (Trnové - Hrnčiarsky vrch), tak vzorky skupiny B byly více ovlivněny přidáváním ostř̌iva tvořeného pravděpodobně říčním pískem Váhu, který se projevuje zvýšeným zastoupením Ti (obr. 8). Toto zjištění koresponduje s instrukcí z artikulů pro žilinský cech hrnčířu (viz kapitolu 3), která uvádí, že kameny do ostřiva byly brány z řeky Váh. Skupina A je mikropetrograficky poměrně heterogenní a je tvořena pravděpodobně vzorky pocházejícími $\mathrm{z}$ různých neznámých zdrojů.

V př́ípadě skupiny A se nejedná a produkční skupinu sensu stricto, ale o keramiku různé provenience s nejednotně ucelenou technologí. Tato skupina byla zachycena výhradně na lokalitě Lietava. Hrad Lietava je dalším dvěma zkoumaným lokalitám vzdálený, a navíc neměl nad městem Žilina nepřetržitou državu. Zásobení keramikou z různých zdrojů se nabízí jako logické vysvětlení vysoké heterogenity skupiny A. Skupiny B a C zastupují keramiku vyráběnou z hlíny, jejíž zdroj či zdroje byly blízké historicky doloženému hliníku v Trnovém. Keramika 


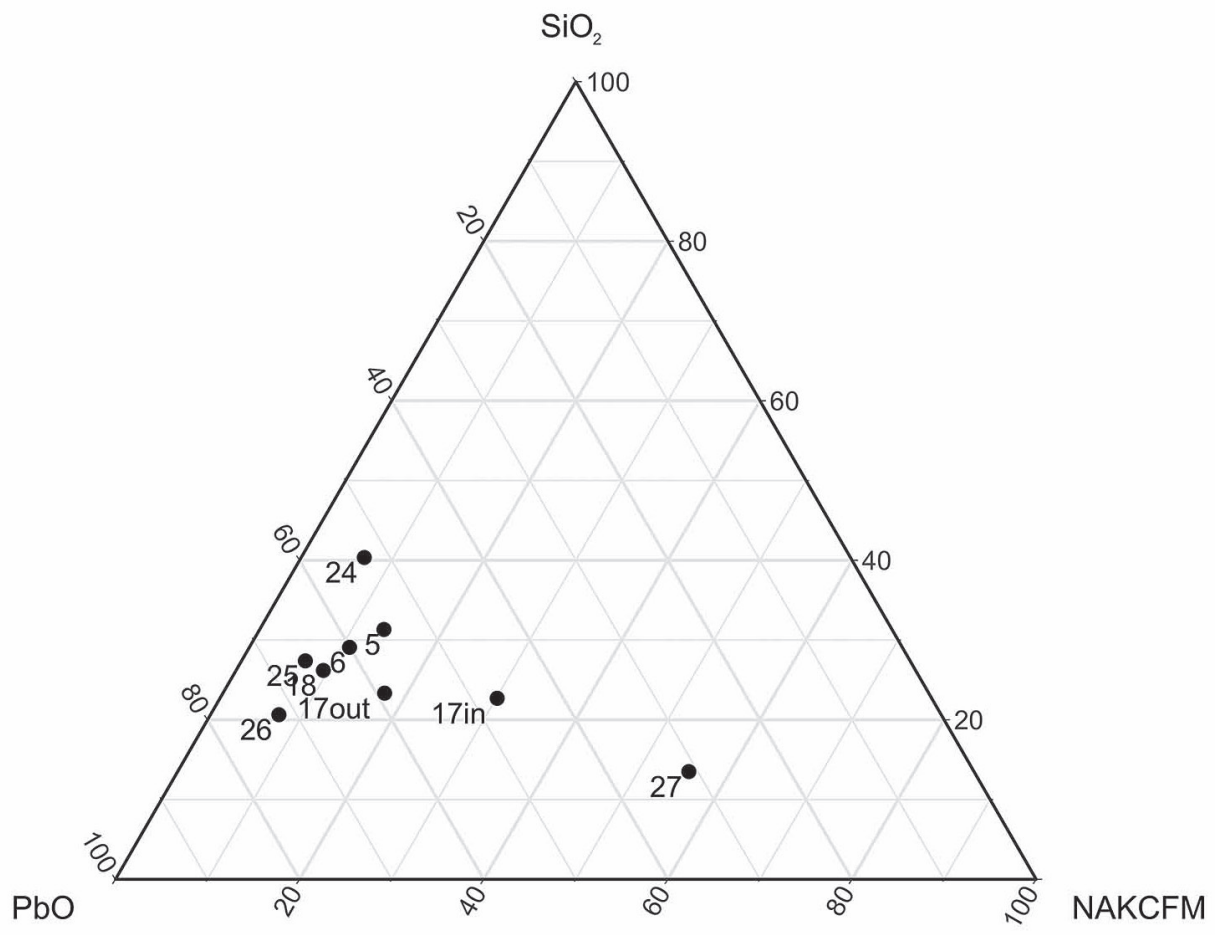

Obr. 9. Ternární diagram chemického složení glazur ukazujíí poměry $\mathrm{PbO}, \mathrm{SiO}_{2}$ a NAKCFM Na $2 \mathrm{O}+\mathrm{Al}_{2} \mathrm{O}_{3}+\mathrm{K}_{2} \mathrm{O}+\mathrm{CaO}+\mathrm{FeO}+\mathrm{MgO}$. Klasifikace podle Tite et al. 1998.

Abb. 9. Ternärdiagramm der chemischen Zusammensetzung der Glasuren mit Darstellung der Verhältnisse $\mathrm{PbO}_{2} \mathrm{SiO}_{2}$ und $\mathrm{NAKCFM} \mathrm{Na} \mathrm{O}_{2}+\mathrm{Al}_{2} \mathrm{O}_{3}+\mathrm{K}_{2} \mathrm{O}+\mathrm{CaO}+\mathrm{FeO}+\mathrm{MgO}$. Klassifikation nach Tite et al. 1998.

skupiny B obsahuje větší poměr ostřiva pocházejícího z písčitých sedimentů řeky Váh. Nejvíce vzorků z této skupiny pochází z Budatína (čtyři zlomky hrnců) a Žiliny (dva zlomky džbánů a jedna poklice), pouze dva vzorky z Lietavy (jeden zlomek hrnce a talíře / jídelní mísy). Jemnozrnná skupina $\mathrm{C}$ byla zastoupena na všech lokalitách, a to osmi kusy hrnců, dvěma džbány a jedním talířem, resp. jídelní mísou.

K území lietavského panství patřilo ve sledovaném období zeměpanské městečko Rajec, ve kterém byly hrnčířské dílny. Městečko samo však hrnčířský cech nemělo. Místní hrnčíři pravděpodobně náleželi k cechu žilinskému, jenž byl jediným cechem v oblasti. Navíc je známo, že v jeho případě šlo spíše o oblastní než striktně městskou organizaci. Hrnčíři, kteří náleželi k žilinskému cechu, chodili prodávat své zboží na rajecké trhy (Jeršová 1970, 68; Lengyelová 2012, 133). Pohyb hrnčířu a jejich výrobků mezi Žilinou a Lietavou dokládá mimo jiné též dopis Juraja Lavrentiho z roku 1644, ve kterém žádá žilinského rychtáře, aby hrnčířský cechmistr zaslal na hrad Lietava hrnčíře, který tam postaví kachlovou pec. Podobně soudobý dopis Juraje Feketeho, který žádá žilinského starostu o urgentní zaslání džbánu na vodku pro hradního pána (Jeršová 1970, 70). Žilina nenáležela v daném období ani do panství lietavského, ani do panství budatínského (Kavuliak 1941, 56-57). Budatín však sousedí přímo s městem, takže je logické předpokládat, že sem keramika proudila z městských dílen. Panství Budatín náleželo poddanské městečko Kysucké Nové Mesto, zde však hrnčiřský cech vznikl až roku 1678 a do té doby nejsou z městečka žádné doklady hrnčířských dílen (Janík 2018; Špiesz 1972, 80). 
Makroskopicky definované keramické tř́idy je vhodné konfrontovat s výsledky analýz. Keramická třída T1 byla zastoupena vzorky z Budatína a Lietavy, a to převážně zadělávacími mísami. Zadělávací mísy z Lietavy spadají do modelové skupiny A, vzorky z Budatína do skupiny B. Makroskopicky určená T1 tedy není homogenní a podle mikropetrografie a chemického složení ji lze rozdělit do dvou skupin (A a B). Keramická tř́́da T2 je zastoupena pouze zlomky hrnců, což umožňuje lepší srovnání. Stejné lokálně závislé rozložení skupin jako u T1 se projevilo i zde. Hrnce z Lietavy náleží téměř výhradně skupině A, hrnce z Budatína výhradně skupině B. Keramickou třídu T3 tvoří vzorky z Budatína, Lietavy i Žiliny a jde o džbán, hrnce a jeden zlomek talírée / jídelní mísy a jedná se o nejvariabilnější keramickou tř́idu, co se týká morfologie. Tato keramická třída je makroskopicky dobře rozlišitelná, což se potvrdilo i provedenými analýzami. Všechny až na jeden vzorek (talír / jídelní mísa, sk. B, Lietava) náleží skupině C. Tř́ída T10, která byla makroskopicky určena jako redukční ekvivalent T2, je zastoupena pouze vzorky ze Žiliny a jedná se o džbány a poklici. Podle mikropetrografického rozboru džbány náleží skupinám $\mathrm{B}$ a $\mathrm{C}$, poklice skupině B. Afinitu T2 a T10 bude možné posoudit v další etapě výzkumu, kdy bude soubor dat rozšířen o další vzorky.

Chemické složení glazur z časně novověké keramiky z lokalit Budatín, Lietava i Žilina je v základu podobné, nebot' se ve všech prŕípadech jedná o vysoce olovnaté glazury. Zkoumané glazury se tedy podobají i většině vrcholně středověkých glazur ze střední a východní Evropy (Auch 2012; Petř́k et al. 2015; Rzeznik-Stoksik 2011). Zvýšeným zastoupením alkálií se odchyluje glazura hrnce z Lietavy (č. vzorku 27). Určitá variabilita se projevuje v zastoupení pigmentů. Mimo vždy prŕítomné železo a téměř vždy zastoupenou měd' (zelená barva) byl identifikován také mangan (černá barva).

\section{Závěr}

Všechny zkoumané nádoby byly vyrobeny z materiálu získaného v zájmovém regionu. Úlomky hornin zjištěné ve vzorcích potvrdily instrukce pro hrnčíře z artikulů žilinského cechu, že se má keramika ostřit pískem z Váhu. Identifikovány byly tři tzv. produkční skupiny, i když skutečná variabilita byla vyšší, protože skupina A představuje technologicky velmi heterogenní keramiku. Skupiny B a C reprezentují homogenní zboží ve smyslu provenience i technologie. Obě se svým chemismem blíží materiálu z hliníku v Trnovém, který leží asi 5 km jihovýchodně od centra Žiliny a je zmiňován $\mathrm{v}$ artikulích hrnčířského cechu. Lze tedy předpokládat, že tuto surovinu používali prrímo žilinští hrnčíři. Skupina B je více ostřená pískem z Váhu nežli skupina C. Bylo zjištěno, že rozdělení hrubozrnnějšího zboží (T1, T2 a A, B) se makroskopicky a mikropetrograficky odlišuje $\mathrm{v}$ jiných ohledech, tudíž není možné pouhým okem tyto dvě třídy přesně rozlišit. Nicméně T1 i T2 zastupují keramiku vrcholně středověké tradice, která v minimální míře pokračuje i na začátku novověku.

Výsledky korespondují s politickou situací v oblasti. Lietava již neměla dominium nad městem Žilina, a tak kuchyňská keramika, kterou byl hrad zásoben, pravděpodobně zčásti ve formě dávek, pocházela nejen od výrobců v Žilině. Nabízí se blízké městečko Rajec, které mělo své hrnčířské dílny. Zboží vrcholně středověké tradice (T1 a T2 - pro Lietavu sk. A) na hrad přicházelo z různých dílen, keramika tradice mladší (T3, sk. C) však již odpovídá produktům Žiliny. Budatín stojí v blízkém sousedství se Žilinou, která sice do jeho panství nespadala, avšak jiné produkční centrum keramiky $\mathrm{k}$ dispozici pro budatínské pány nebylo. Zjištění této studie odpovídají závěru, že jak keramika starší tradice (T1 a T2 - pro Budatín sk. B), tak mladší (T3, sk. C) je produktem hrnčířu pracujících ve městě či jeho okolí.

Zkoumané glazury svým složením korespondují s glazurami, které se v této části Evropy běžně používaly od vrcholného středověku. Všechny zkoumané vzorky byly polity vysoce olovnatou glazurou, která byla $\mathrm{v}$ prrípadě zelené barvy obohacena oxidy mědi. Jediný mírně odlišný vzorek pochází z Lietavy, a jeho odlišnost spočívá ve zvýšeném obsahu alkálií. Černé barvy některých glazur bylo docíleno přidáním manganu. 
Tato pilotní studie ukázala potenciál výzkumu raně novověké keramiky v oblasti severozápadního Slovenska. Množství písemných pramenů, vznikající hrnčiřsské cechy a celková dynamika v politické geografii regionu umožňují zapojit keramické nádoby coby produkty denní potřeby, mezi zdroje poznání při rekonstrukci vztahů mezi lidskými sídly té doby. Dalším logickým krokem bude rozbor většího vzorku materiálu, tak aby bylo možné použít vypovídací hodnotu jednotlivých keramických tvarů jako interpretační nástroj. Předpokládáme, že na nádoby kuchyňské a jemnější, tedy stolní, byly jejich uživateli kladeny různé nároky, tudíž by hrnce či zadělávací mísy měly ukázat větší regionální závislost.

Studie byla podpořena projektem NAKI II - Vrcholně středověká keramika jako součást movitého kulturního dědictví DG18P02OVV020. Poděkování náleží též projektům LM2015056 a LM2015074, což jsou CANAM a Experimentální jaderné reaktory LVR-15 a LVR-0.

\section{Literatura}

AUCH, M., 2012: Wczesnośredniowieczne naczynia szkliwione z terenu zachodniej Małopolski, Archeologia Polski 57, 199-246.

BIELICH, M., v tisku: Predbežné výsledky archeologického výzkumu Lietavského hradu v rokoch 20082019, Oravský zborník XXXVI.

BEDNÁR, P.-STANEKOVÁ, Z., 2009: Výsledky archeologického výskumu Budatínskeho zámku, Archeologické výzkumy a nálezy na Slovensku 2007, 29-31.

BLAŽKOVÁ, G., 2013: Vývoj raně novověké kuchyňské a stolní keramiky v Čechách na základě souborů z Pražského hradu - The development of Early Modern ceramic kitchenware and tableware in Bohemia based on assemblages from Prague Castle, PA CIV, 183-230.

BLAŽKOVÁ, G.-MATĚJKOVÁ, K., 2016: Novověká odpadní jímka z Pražského hradu - A Modern Period Waste Pit from Prague Castle. In: Castrum Pragense 13. Katalog hmotné kultury z renesančních odpadních jímek z Pražského hradu. Díl II. Studie (Blažková, G.-Vepřeková, J., edd.), 115-204. Praha.

BOTOŠ, A., 2012: Novoveká studňa z Rimavskej Soboty, ZbSNM CVI Archeológia 22, 235-249.

ČAPEK, L. et al., 2018: Čapek, L.-Těsnohlídková, K.-Slavíček, K.-Všianský, D.-Pracný, P., Technologie výroby a archeometrické studium středověké keramiky. Plzeň - Brno.

ČURNÝ, M., 2004: Keramika zo 16.-18. stor. na juhozápadnom Slovensku na príklade nálezov z kaštiel’a v Lukáčovciach. Rkp. disertační práce, ulož. na Univerzitě Konštantína Filozofa v Nitre.

FEKETE-NAGY, A., 1941: Trencsén vármegye. Budapest.

GREGEROVÁ, M. a kol., 2010: Petroarcheologie keramiky v historické minulosti Moravy a Slezska. Brno.

GYÖRKÖS, D. et al., 2018: Györkös, D.-Bajnóczi, B.-Szakmány, G.-Szabó, M.-Balogh-László, E.Tóth, M., A besztercebányai (banská bystrica) típusú kályhacsempék archeometriai kutatásának előzetes eredményei - Preliminary results of the archeometric investigation on the so-called Besztercebánya / Banská Bystrica type stove tiles, Archeometriai Mühely 15, č. 1, 45-56.

HOŠŠO, J., 1983: Prehl’ad vývoja stredovekej keramiky na Slovensku - Entwicklungsübersicht der mittelalterlichen Keramik in der Slowakei, AH 8, 215-231.

- 1988: Hrnčiarstvo, remeslo stredovekej dediny a mesta vo svetle archeologických prameňov, Historica 35-36, 105-139.

- 2004: Hranica medzi stredovekom a novovekom vo svetle archeologických nálezov keramiky - Die Grenze zwischen dem Mittelalter und der Neuzeit im Lichte der archäologischen Keramikfunde, AH 29, 569-580.

JANÍK, M., 2018: Kysucké Nové Mesto - Najstaršie mesto na Kysuciach. Dostupné z: https://www.kysuckenovemesto.sk/historia-mesta.html, cit. 22. 3. 2020.

JERŠOVÁ, M., 1960: Príspevok k dejinám hrnčiarstva a keramiky na Slovensku, Historické štúdie 6, 311-319.

- 1970: Z dejín hrnčiarstva v Žiline, Vlastivedný zborník Považia X, 67-75. 
KAVULIAK, A., 1941: Rajecký kraj. Historicko-hospodárska štúdia, Sborník muzeálnej slovenskej spoločnosti XXXIV-XXXV, 1940-41.

KURUCÁROVÁ, J., 2012: Rod Thurzovcov a Štátny archív v Bytči. In: Thurzovci a ich historický význam (Lengyelová, T., ed.), 227-238. Bratislava.

LENGYELOVÁ, T., 2012: Hospodárske pomery na thurzovských panstvách na prelome 16. a 17. storočí. In: Thurzovci a ich historický význam (Lengyelová, T., ed.), 119-134. Bratislava.

MACKIEWICZ, M.-STOKSIK, H., 2012: Nowożitna keramika artystyczna z badań archeologicznych przy Kościele św. Piotra i Pawla na Ostrowie Tumskim we Wrocławiu. In: Wratislavia Antiqua 17 - Ze studiów nad życiem codziennym w średnioweiczmym mieśce, Nowożytny cmentar przy Kościele W. Piotra i Pawła na Ostrowie tumskim we Wrocławiu (1621-1670) (Pankiewicz, A., ed.), 129-160. Wrocław.

MÁJSKY, R., 2003: Záchranný výskum v intraviláne Púchova, AVANS 2002, 87-88.

MATĚJKOVÁ, K., 2011: Contribution of Scientific Analyses to the Archaeological Assessment of Pottery Production in Turnov, Czech Republic, Interdisciplinaria archaeologica 2, č. 2, 125-138.

MORAVČÍK, J., 1970: Najnovšie archeologické nálezy v okrese Žilina, Vlastivedný zborník Považia X, 5-26. PAJER, J., 1983: Počátky novověké keramiky ve Strážnici. Strážnice.

PETŘÍK, J.-SLAVÍČEK, K.-SEDLÁČKOVÁ, L., 2015: Petrografie keramiky. In: Veselí nad Moravou. Středověký hrad v říční nivě (Plaček, M.-Dejmal, M., edd.), 102-112. Brno.

PLICKOVÁ, E.-SCHEUFLER, V., 1966: Lidová hrnčina v Československu. Kultura a tradice 6. Uherské Hradiště.

POLLA, B., 1962: Stredoveká zaniknutá osada na Spiši (Zalužany). Bratislava.

- 1986: Košice Krásna. K stredovekým dejinám Krásnej nad Hornádom. Košice.

QUINN, P., 2013: Ceramic Petrography - The Interpretation of Archaeological Pottery and Related Artefacts in Thin Section. Oxford.

R CORE TEAM 2014: R: A language and environment for statistical computing. R Foundation for Statistical Computing. Vienna.

RZEŹNIK, P.-STOKSIK, H., 2011: Problem of the glazed ceramics production in the pottery of Medieval Silesia, AR LXIII, 466-484.

SZWED, R., 2004: Wczesnonowożytna ceramika naczyniowa z ulicy św. Antoniego we Wrocławiu. In: Wratislavia Antiqua 6 - Wrocław na przełome średniowiecza i czasów nowożytnych. Materialne przejawy życia codziennego (Piekalski, J.-Wachowski, K., edd.), 331-383. Wrocław.

ŠIMKOVIC, M., 2014: Architektonicko-historický výskum a metodika konzervácie a čiastočnej obnovy hradu Lietava 2003-2013. In: Zborník z vedeckej konferencie 20.-21. júla 2014. Hrad Lietava 20032013 (Chobot, L., ed.), 22-29. Lietava.

ŠPANIHEL, S., 2014: Stredoveká a novoveká keramika severozápadného Slovenska, ŠZ AÚ SAV 55, 141-179. - 2015: Nálezy keramiky z obranných priekop mesta Žilina - Keramikfunde aus Verteidigungsgräben der Stadt Žilina, AH 40, 857-875.

- 2017: Keramika a jej možnosti pri periodizácii raného novoveku na Slovensku, Pravěk NŘ 25, 293 -314.

- 2019: Novoveká stolová a kuchynská keramika zo severozápadného Slovenska na príklade nálezov z hradu Lietava. Rkp. disertační práce, ulož. na MU, Brno.

ŠPIESZ, A., 1972: Remeslo na Slovensku v období existencie cechov. Bratislava.

TĚSNOHLÍDKOVÁ, K.-SLAVÍČEK, K.-VŠIANSKÝ, D., 2019: Keramický soubor z trati Ohrada u hradu Lichnice - Die Keramikkollektion von der Lage Ohrada bei Burg Lichnice, AH 44, 383-419.

THERNEAU, T.-ATKINSON, B., 2019: Rpart: Recursive Partitioning and Regression Trees. R package version 4.1-15. Dostupné z: https://CRAN.R-project.org/package=rpart.

TITE, M. S.-FREESTONE, I.-MASON, R., 1998: Lead Glazes in Antiquity - Methods of Production Methods of Production and Reasons for Use, Archaeometry 40, 241-260.

VANGEL, J.-DECKÝ, M.-REMIŠOVÁ, E., 2007: Mining and application history of nature asphalt at area of Nezbudská Lúčka, Civil and environmental engineering 3(2), 102-108.

VITKÓOVÁ, A., 2015: Živnostenská správa v období dualizmu, Visegrad Journal on Human Rights (1867-1918), 2/2014, 82-86

VOZÁR, J.-KÁČER, Š. a kol., 1998: Geologická mapa Slovenskej republiky, M 1 : 1000000. 
ULIČNÝ, M., 2004: Premeny východoslovenskej keramiky v 13.-17. storočí (Na podklade analýzy keramického fondu z hradu Šariš). Rkp. disertační práce, ulož. v Archeologickém ústavu SAV v Nitre.

ZDANIEWICZ, R., 2012: The ceramic series from the town Square in Gliwice. In: Wratislavia antiqua 16 Archaeology of a pre-industrial town in Silesia. Case study Gliwice (Michnik, M.-Piekalski, J., edd.), 82-101. Wrocław.

ŽEGKLITZ, J., 1990: Topografie pražských hrnčířských den a jejich podoba v 16.-17. století - The topografy and outlook of pottery workshops on Prague in the 16th and incident 17th century. In: Studies in Post-Medieval Archaeology 1 (Smetánka, Z.-Žegklitz, J., edd.), 215-230. Praha.

ŽEGKLITZ, J.-ZAVǨEL, J., 1990: Geochemical and petrographical studies of the post-mediaeval pottery of the Prague and Beroun regions. On the questions of raw-material sources and prohnance. In: Studies in Post-Medieval Archaeology 1 (Smetánka, Z.-Žegklitz, J., edd.), 95-126. Praha.

\section{Zusammenfassung}

\section{Archäometrisches Studium frühneuzeitlicher Keramik aus der Nordwest-Slowakei (Žilina, Budatín und Lietava)}

Für die Zwecke dieser Erststudie wurden 27 Fragmente frühneuzeitlicher Keramik naturwissenschaftlichen Analysen unterzogen. Dabei handelte es sich um Töpfe, Anrührschüsseln, Essschüsseln / Teller, Krüge und um einen Glockendeckel. Die Proben stammten aus drei einander nahegelegenen Fundstellen in der nordwestlichen Slowakei - aus Žilina, von Schloss Budatín und von der Burg Lietava. Ziel war es, eine mikropetrographische Grundcharakteristik des Materials zu erstellen und erste Daten über die chemische Zusammensetzung, das Herstellungsverfahren und die Provenienz der glasierten Keramik heimischer Produktion aus der Nordwest-Slowakei zu erhalten. Ferner wurden sechs Proben potenzieller Rohstoffe analysiert. Als Quellen für Keramiklehm wurden zwei historisch belegte Lehmgruben (Trnové - Töpferberg Hrnčiarsky vrch und Bytčica Lehmgrube Hlinisko) und als Quelle für Magerungsmittel die Sande des Flusses Waag getestet.

Für die Analyse der chemischen Zusammensetzung der Keramikmasse und die mikropetrographische Analyse wurden die Vertreter von vier makroskopisch definierten Keramikklassen gewählt. Bei den Klassen der hochmittelalterlichen, den Produktionsgruppen A und B entsprechenden Tradition haben sich regionale Abweichungen zwischen den Adelssitzen Budatín und Lietava gezeigt. Budatín wurde von Werkstätten aus Žilina mit Küchenkeramik versorgt. Lietava erhielt Keramik aus anderen Werkstätten, in deren Rahmen eine Heterogenität im Charakter der Keramikmatrix und in der Menge des Magerungsmittels erkennbar war. Als Magerungsmittel hat man Sand aus den Sedimenten der Waag verwendet. Mit analytischen Methoden wurden auf diese Weise Informationen aus der Zunftordnung Žilinas verifiziert. Keramik jüngerer Tradition (Gruppe C) wurde ausschließlich in Žilina hergestellt, deren Werkstätten die Ware für alle untersuchten Fundstellen vertrieben. Festgestellt wurde eine Affinität in der chemischen Zusammensetzung des Keramiklehms von der Fundstelle Trnové - Hrnčiarsky vrch und den Produktionsgruppen B und C, die als Erzeugnisse städtischer Töpfer interpretiert wurden.

Die chemische Zusammensetzung der Glasuren wurde anhand von Oberflächenanalysen von acht Proben ermittelt. Festgestellt wurde, dass es sich um eine quarzhaltige, sehr bleihaltige Glasur handelte, die in dieser Zeit üblich war. Als Farbstoffe wurden die Oxide von Kupfer, Eisen und Mangan verwendet. Kupfer produziert grüne Töne, mit Manganbeigabe erhält die Glasur eine rote Farbe.

Die vorliegende Studie wurde vom Projekt NAKI II - Hochmittelalterliche Keramik als Bestandteil des beweglichen kulturellen Erbes DG18P02OVV020 gefördert. Ein Dank gebührt auch den Forschungsprojekten LM2015056 und LM2015074, d.h. CANAM und Experimentelle Kernreaktoren LVR-15 und LVR-0. 
Mgr. Karel Slavíček, Ústav archeologie a muzeologie Filozofické fakulty Masarykovy univerzity, Arna Nováka 1, 60200 Brno; Ústav geologických věd Př́rodovědecké fakulty Masarykovy univerzity, Kotlářská 267/2, 61137 Brno, Česká republika, slav.karel@mail.muni.cz

Mgr. Jan Petřík, Ph.D., Ústav archeologie a muzeologie Filozofické fakulty Masarykovy univerzity, Arna Nováka 1, 60200 Brno; Ústav geologických věd Přírodovědecké fakulty Masarykovy univerzity, Kotlářská 267/2, 61137 Brno, Česká republika, petrik.j@sci.muni.cz

Mgr. Samuel Španihel, Muzeum regionu Valašsko, p. o., Horní náměstí 2, 75501 Vsetín, Česká republika, spanihel@muzeumvalassko.cz 

